\title{
Multinationals and the Globalization of R\&D
}

by

\author{
María García-Vega, Patricia Hofmann and Richard Kneller*
}

\begin{abstract}
In this paper we consider how the location, organization and output of knowledge production evolve within domestic firms following acquisition-FDI in order to understand the aggregate effect on an index of domestically produced innovations. We find strong differences according to how close the acquiring MNE is to the technologically frontier. Frontier MNEs are more likely to close R\&D activities in acquired affiliates, but when they are retained they expand employment of high-skilled R\&D workers and transfer R\&D knowledge. Non-frontier MNEs make fewer changes to $R \& D$. Overall the effect of acquisition-FDI on the domestic innovation index is positive.
\end{abstract}

JEL classification: F23; O32; D22; L20

Keywords: MNE; Knowledge Production Function; Acquisition FDI; Knowledge Complementarities; R\&D: innovation, Technology Transfers.

\footnotetext{
* García-Vega: School of Economics, University of Nottingham, University Park, Nottingham NG7 2RD, United Kingdom and GEP (email: maria.garcia-vega@nottingham.ac.uk); Hofmann: Department of Economics, University of Hohenheim, D-70593 Stuttgart, Germany (email: p.hofmann@uni-hohenheim.de); Kneller: School of Economics, University of Nottingham, University Park, Nottingham NG7 2RD, United Kingdom, GEP and CESIfo (email: richard.kneller@nottingham.ac.uk). We would like to thank Joel Stiebale for his very helpful comments and Sourafel Girma for providing the program to calculate treatment effects. We thank Johannes Biesebroeck, Giammario Impullitti, Simon Gächter, Beata Javorcik, and María Rochina for their helpful comments as well as seminar participants at the University of Nottingham, Trento, and 14th ETSG Conference (Leuven), ZEW (Mannheim) and 5th ISGEP workshop (Ljubljana), ICTNET workshop (London), 27th EEA Conference (Malaga), 39th Annual EARIE Conference (Rome), Royal Economic Society Annual Conference (Sussex).
} 


\section{Introduction}

Modern theories of growth and development (Acemoglu, 2007; Arora et al., 2011; Bloom et al., 2012; Aghion et al., 2014) emphasise technology and its evolution as an explanation for differences in income levels across countries. This technology stock is usually defined as the sum of that produced domestically, together with the technologies that have diffused internationally in an embodied or disembodied form (Coe and Helpman, 1995; Keller, 2004). Multinational firms (MNEs) are at the heart of discussions around the determinants of this stock as they account for the majority of global R\&D expenditures and share their knowledge across their international affiliates (Helpman, 1984; Markusen, 1984; Branstetter et al., 2006; Keller and Yeaple, 2013).

Globally, most foreign direct investment (FDI) takes the form of mergers and acquisitions, often involving R\&D active firms (UNCTAD, 2005, 2007). Such acquisitions therefore impact domestic technology levels, but how? Guadalupe et al. (2012) show that acquired subsidiaries increase technology adoption as a result of their access to a larger market. But, what are its effects on the domestic innovation capability of acquired firms and what are its aggregate effects? ${ }^{1}$ What happens with research employment? Do subsidiaries become more reliant on international technology transfers versus domestic production of knowledge, are there differences across types of MNEs, and does this alter the productivity of the innovation process? To answer these questions, we examine the effects of acquisition-FDI on the production of knowledge by acquired firms and then combine these to describe the evolution of an aggregate domestic technology index.

The starting point for our analysis assumes that MNEs have the incentive to generate and to share knowledge across their affiliates as efficiently as possible and will therefore alter R\&D structures in response to new acquisitions (Helpman, 1984; Markusen, 1984; Branstetter et al., 2006; Keller and Yeaple, 2013). We capture these changes by following changes in the probability of starting and shutting down research labs, and then conditional of keeping research facilities, we study changes in internal and external $R \& D$ spending, $R \& D$ employment disaggregated by level of education and patents per euro of expenditure of acquired firms in the time periods following acquisition. We use a difference-in-differences approach with non-acquired domestic firms as a counterfactual. To control for possible selection on observables, we use the propensity score matching previously deployed to

\footnotetext{
${ }^{1}$ Acquisition-FDI is sometimes subject to fierce political scrutiny because of fears it can damage domestic technology levels. For example, the proposed takeover of the British-Swedish firm AstraZeneca by Pfizer in 2014 led to requests for guarantees for the retention of research jobs in the UK from the Prime Minister, the leader of the Opposition and the president of the Royal Society.
} 
study the productivity and employment effects of foreign acquisitions by Chen (2011), Criscuolo and Martin (2009); Greenaway and Kneller (2007) and Guadalupe et al. (2012) amongst others. ${ }^{2}$

To capture the aggregate effects on domestic innovation we calculate the change in an index of domestically produced innovations per euro of expenditure following a period of acquisition-FDI. Within this index, the aggregate effect of FDI depends upon the response of innovation outputs within acquired firms (a within-firm effect measuring the change in innovation output per euro of expenditure keeping constant the innovation spending of the firm), but also between firm reallocation effects (measuring the change in innovation spending keeping innovation output constant), a cross effect (measuring the change in output and spending) and an entry and/or exit effects (measuring the start, or cessation of R\&D). ${ }^{3}$ We also allow these outcomes to differ across acquisitions, with different responses when the acquiring-MNE is closer to the technological frontier. This paper represents the first attempt in the literature to model the effects of acquisition FDI on the evolution of R\&D output together with its location and organization within acquired firms in this way.

The data we use are an annualized version of the Spanish Community Innovation Survey (CIS) and contain detailed information on expenditures, employment and innovation outputs. Within the time period we study (2004 to 2009) there are 300 acquisitions of R\&D active domestic firms. These represent $3.7 \%$ of total Spanish R\&D expenditures, indicating the importance of understanding the effect of changes in ownership of this type. ${ }^{4}$ Consistent with versions of the CIS for other countries, the data include a direct measure of R\&D technology transfers within the MNE: imports of knowledge from the business group. ${ }^{5}$ That Spain represents a country that would not typically being viewed as on the technological frontier provides an important aspect of our investigation as it ensures heterogeneity in these knowledge transfers across MNEs that we then exploit empirically. ${ }^{6} \mathrm{We}$ consider frontier foreign acquisitions if the MNE is headquartered in a technologically intensive country or not. In the baseline regressions we adopt a conservative classification and include only MNEs from Germany Japan, and USA as technological frontier countries. Of the 300 acquisitions, 104 are by frontier MNEs and 196 are MNEs that are behind the technological frontier.

\footnotetext{
${ }^{2}$ If the acquisition decision was driven by non-R\&D factors that are correlated with observable affiliate characteristics such as size this will be controlled for through our matching exercise. If it was driven by unobservable time-invariant heterogeneity related either to the affiliate it will be controlled for through the difference-in-differences approach.

${ }^{3}$ This approach was originally applied to decompose aggregate productivity.

${ }^{4}$ In Spain, $22 \%$ of total R\&D expenditures are by foreign owned firms. This compares to $19 \%$ of total US R\&D spending (NSF, 2016) and 25\% in Germany (DIW, 2016).

${ }^{5} \mathrm{R} \& \mathrm{D}$ imports do not include royalties, licenses, trademarks or franchise fees (those are included in a different question of the survey).

${ }^{6}$ According to the European Commission, Spain is considered a 'moderately' innovative country (European Innovation Scoreboard, 2009).
} 
From the analysis we are able to show that the acquisition of R\&D active firms by foreign MNEs has a positive effect on the stock of domestically produced knowledge, accounting for $7.14 \%$ of the growth in the Spanish technology index over a 5-year period. This is a significant change in the domestic technology production caused by acquisition-FDI, in particular given these firms accounted for a smaller share of expenditures (3.7\%). A large part of this increase is accounted for by the within effect; the innovation output of acquired firms increases. This increase is driven by changes that occur when acquisition is from a technological frontier MNE. For these firms, we find evidence of skillupgrading and large increases in technology transfers of scientific knowledge from elsewhere within the MNE. These positive within effects are offset to some extent by negative between effects, as R\&D expenditures fall when acquisition is by a non-technologically-leading MNE and by the increased risk the R\&D labs are closed by frontier MNEs.

An explanation for our results is that R\&D active MNEs face an opportunity cost of choosing a globalized R\&D strategy and retaining innovation within the acquired subsidiary, versus the closure of the acquired lab and the relocation of this $R \& D$ effort elsewhere. These opportunity costs can be because innovation is produced with increasing returns to scale as in Arkolakis et al. (2014) or because there are localized knowledge spillovers as in the model of Ekholm and Hakkala (2007). These incentives are likely to vary with the technological leadership of the MNE. If the opportunity cost is high, as it might be for technologically frontier MNEs, the acquired R\&D lab may be closed and knowledge creation concentrated within a single location. Alternatively the MNE will exploit complementarities in the knowledge base across different locations by sharing its scientific knowledge between its labs. ${ }^{7}$ The MNE will then retain the affiliate R\&D lab and decentralize R\&D globally. If the technology transfers that occur in this outcome are complementary to high-skilled personnel, then the $R \& D$ process in the acquired lab will also be restructured to take advantage of intrafirm knowledge transfers. Frontier MNEs have more valuable knowledge to share and might undertake the greatest reorganisation, thereby increasing the retained $\mathrm{R} \& \mathrm{D}$ lab's rate of innovation by the greatest amount. ${ }^{8}$

\footnotetext{
${ }^{7}$ For example, Nocke and Yeaple (2008) discuss the importance of complementarities as a determinant of acquisitions. Moraga et al. (2018) study the effect of mergers on R\&D investments when firms have different R\&D projects that differ in their degree of innovativeness. For a summary on the literature of R\&D complementarities between merging firms see Jullien and Lefouili (2018). The Financial Times (2014) reports the growing importance of collaboration and sharing technology across different labs to generate innovations. These flows of R\&D are economically important. For example, the National Science Foundation (NSF, 2012) reports that, in the US during 2009, the exports and imports of R\&D and testing were $\$ 18.2$ billion and $\$ 15.8$ billion, respectively, most of them within MNEs. This represents $1.7 \%$ and $1.5 \%$ of exports and imports of trade in goods respectively
}

${ }^{8}$ Regarding the reorganization of the R\&D, Federico et al. (2017) consider that R\&D might decline after merger activity due to $R \& D$ duplication or substitutability of some innovative activities. 
A different mechanism that can also lead to an increase in innovation expenditures following acquisition are due to a market size effect as in Guadalupe et al. (2012) or Denicolò and Polo (2018a). In the model of Denicolò and Polo (2018a), innovation is not firm-specific, and therefore mergers might increase innovation and the sharing of technologies because the scope for the application of new technologies increases. ${ }^{9}$ Therefore, the effects of acquisition-FDI depend upon the survival of R\&D labs, together with the effects on the organization of $R \& D$ that might arise from knowledge complementarities or sharing technologies within a globalized R\&D structure.

Our findings make novel contributions to the literature on innovation and acquisition-FDI. For Spain, Guadalupe et al. (2012) find that technology adoption increases in acquired affiliates. Stiebale (2016) extends this literature to show that innovation in the merged entity as a whole rises. Of interest, he shows that this occurs largely as a consequence of a rise in innovation in the acquirer, with declines in innovation for the acquired affiliate. In contrast, we find that innovation in the acquired firm rises, but only for those acquired by technologically-frontier MNEs. This rise in innovations combined with declines in expenditures, suggest rising productivity and therefore our findings provide a novel explanation for the ample evidence for productivity improvements that follow from acquisition FDI (Arnold and Javorcik, 2009; Criscuolo and Martin, 2009; Chen, 2011). ${ }^{10}$

We also make a contribution to a literature that explores partial effects of acquisition-FDI on total R\&D expenditures. These results appear to depend strongly on the country being considered, with a mix of positive and negative effects found for total R\&D spending (Bandick et al., 2014; Stiebale and Reize, 2011) and on the empirical literature of the effect of mergers on R\&D (Bertrand and Zuniga, 2006; Szücs, 2014; Haucap et al., 2018). Compared to these articles, we study total expenditures alongside other organisational changes, including closure, and also how acquisition affects innovation output. Moreover, we analyse indirect effects of FDI-acquisition, or in other words, we study the impact of acquisition on $R \& D$ for the non-acquired firms.

Finally, we can relate our findings to a number of different avenues of research on MNEs found in the existing literature. Firstly, they are consistent with a number of stylised facts about the R\&D behaviour of MNEs. Alongside being major producers of new technologies (Criscuolo et al., 2010, Dunning and Lundan, 2008; Javorcik, 2010) MNEs are more globalised in their R\&D locations than

\footnotetext{
${ }^{9}$ The increased probability of shutting research labs following acquisition provides support to the theoretical model of Denicolò and Polo (2018b).

${ }^{10}$ See also Harris and Robinson (2002), Girma et al. (2007), Greenaway and Kneller (2007), Arnold and Javorcik (2009), Keller (2010), and Maksimovic et al. (2011) among others.
} 
non-MNEs (Bloom and Griffith, 2001; NSF, 2011; Guadalupe et al., 2012). ${ }^{11}$ They have also been shown to use more intensively knowledge sourced internationally within their R\&D production function (Veugelers and Cassiman, 2004; Criscuolo et al., 2010) and transfer knowledge to their affiliates (Branstetter et al., 2006; Bilir and Morales, 2015).

The rest of the paper is organized as follows. Section 2 details the data used and Section 3 the empirical methodology. Section 4 describes our main empirical results and provides an overall quantification of the effect of foreign acquisition on the domestic knowledge production. Section 5 presents some tests for the robustness of our main findings including pre-existing trends, an alternative definition of frontier-MNEs and measures of indirect effects using the methodology of Girma et al. (2015) that controls by Stable Unit Treatment Value Assumption (SUTVA) violation. Finally, we draw the conclusions from the study in Section 6.

\section{Data}

The data we use is drawn from an annual survey of Spanish firms called Panel de Innovación Tecnológica (PITEC). ${ }^{12}$ This survey has been conducted since 2004 by the Spanish National Institute of Statistics as an annualised version of the Spanish Community Innovation Survey (EUROSTAT). We use information for all years between 2004 and 2009. The survey is designed to be an unbalanced panel, representative of firms operating in the manufacturing and service sectors. Each year firms are asked to provide information on a number of key performance characteristics, such as sales, employment, ownership, industry and, of interest in this paper, innovation activities. In order to study the effects of acquisition-FDI relative to a counterfactual of non-acquired firms, we exclude from the sample firms that are always foreign owned, those that were acquired more than once, public firms and those without R\&D expenditures throughout the sample period. Our final sample contains 7,719 firms.

To construct our measure of acquisition-FDI we use information on the ownership of the firm, specifically the country location of the headquarters of the owner, and the proportion of equity they hold. We identify foreign acquisitions by a change in the majority equity holder of the firm to one

\footnotetext{
${ }^{11}$ Bloom and Griffith (2001) provide detailed evidence on the internationalisation of R\&D amongst the G5 countries. According to the National Science Foundation (NSF, 2016) around 13\% of all expenditures on R\&D by American MNEs are conducted outside of the United States.

${ }^{12}$ For details of the survey see http://icono.fecyt.es/PITEC/Paginas/descarga_bbdd.aspx.
} 
where control is outside of Spain (i.e. who controls more than $50 \%$ of the equity) ${ }^{13}$ There are 300 acquisitions of domestic firms by foreign multinationals during the period 2004-2009. These acquisitions are from 27 different countries, with the three-quarters accounted for by just seven countries (France 53, Germany 49, US 49, UK 25, Italy 20, Netherlands 19 and Switzerland 12).

We are interested in differences between frontier and non-frontier foreign acquisitions. We consider frontier foreign acquisitions if the MNE is headquartered in a technologically intensive country. In the baseline regressions we follow Acemoglu (2009) and adopt a conservative classification of frontier as including only MNEs from Japan, Germany and USA. In the analysis we label these as frontier acquired and remaining acquisitions as non-frontier acquired. Under this definition there are 104 acquisitions from frontier countries and 196 from non-frontier countries, mostly from other EU countries. We test the robustness of our findings to an alternative categorisation of frontier acquisitions in Section 5.

The PITEC data provides a large amount of detail on innovation including innovation expenditures. Summary statistics for these are shown in Table 1, while Table A1 in A1 in the On-line Appendix A provides definitions for each line of spending. The most aggregated measure of expenditure in the survey is labelled total innovation expenditures. This includes three categories of spending: internal $R \& D$ (R\&D undertaken within the firm within Spain); spending on external $R \& D$ (a firm's purchases of $R \& D$ conducted by other firms, including other plants from the same business group in other countries); and non- $R \& D$ expenditures (which includes expenditures on training for workers, product alternations, market research and advertising). ${ }^{14}$ The data allow for further disaggregation of external $R \& D$ into domestic purchases or imports, which we label external-domestic $R \& D$, and externalforeign $R \& D$ expenditures, respectively. ${ }^{15}$ Finally, the survey also provides information on R\&D spending by type of provider. With this information, we can further separate external-foreign $R \& D$ expenditure into imports of knowledge from the headquarters and from other affiliates within the same business group abroad. Following Criscuolo et al., (2010) we use this to measure $R \& D$ technology

\footnotetext{
${ }^{13}$ This measure is consistent with Balsvik and Haller (2010), Bandick et al. (2014), Guadalupe et al. (2012) and Javorcik and Poelhekke (2017). It defines who has ultimate control of the acquired firm.

${ }^{14}$ External $R \& D$ expenditures are defined as: "Acquisitions of $R \& D$ services through contracts, informal agreements, etc. Funds to finance other companies, research associations, etc, which do not directly imply purchases of R\&D services are excluded". R\&D services are defined as: "Creative work to increase the volume of knowledge and to create new or improved products and processes (including the development of software)". They specifically exclude licenses and royalties, which are a different question in the survey.

${ }^{15}$ For the average firm, external domestic spending accounts for the majority of total external R\&D expenditures (93\% on average).
} 
transfers within the MNE. ${ }^{16}$ Within the estimations we express all R\&D expenditures as a share of total innovation expenditure, except for total innovation expenditures where we use the logged value.

In order to calculate the aggregate effects of FDI we need to be able to identify episodes of entry and exit from $R \& D$. We describe firms as $R \& D$ active, if they record positive internal $R \& D$ expenditures. This is the value of R\&D expenditures conducted within Spain. We denote as quitters those firms with positive internal $\mathrm{R} \& \mathrm{D}$ expenditures in period $t-1$ that then record zero expenditures in period $t$, and do not record positive values in any future time period, $t+s$ with $s \geq 1$. Entrants are those with zero internal $\mathrm{R} \& \mathrm{D}$ expenditures in period $t-1$ that then record positive expenditures in period $t$, and in future time period, $t+s$ with $s \geq 1 .{ }^{17}$

Within the data, 3,530 non-acquired firms cease $R \& D$ at some point during the sample period, which represents $47 \%$ of the 7,719 non-acquired firms. Of the 300 acquired firms, 117 cease their R\&D operations post-acquisition, some $39 \%$ of acquired firms. This would appear to suggest that acquisition-FDI reduces the likelihood that $R \& D$ facilities in Spain will be shut, but as we show below, foreign MNEs are more likely to acquire 'better-performing' firms. As such firms are less likely to shut-their R\&D, such a conclusion is premature. In comparison to the rate at which acquired firms stop R\&D, starting R\&D post-acquisition occurs very infrequently. There are just 8 firms in the dataset that are acquired and then switch from zero to positive internal R\&D expenditures.

The dataset also contains information on the employment of R\&D personnel. Rather than aggregate these, we use them as they are reported in the original data; that is as total employment, and then by education level, employees with a PhD, employees with a 5-year BA degree, employees with a 3-year BA degree and employees without higher education.

\section{Empirical strategy}

Our goal in the paper is to study empirically the change in R\&D outputs, expenditures and entry/exit due to acquisition FDI. The fundamental evaluation problem for such a question is that the counterfactual outcome of not being acquired is unobserved. Our approach follows standard practice in the literature and we combine matching with difference-in-differences. The difference-indifferences (DID) method allows us to follow changes to R\&D between the pre- and post-acquisition

\footnotetext{
16 This measure does not include other forms of technology transfer from the parent such as those of organisation capital, software or management technologies. The PITEC data does not include information on such types of technology transfer. ${ }^{17}$ Our results are robust to an alternative classification of R\&D quitters based on zero R\&D expenditures in two consecutive years.
} 
time periods, versus those in firms that have not been acquired (control group). The regression equation is specified such that it removes the influence of observable and unobservable non-random elements of the acquisition decision that are constant or strongly time persistent. We also remove the effect of time-specific shocks to the economy that might affect R\&D for all firms. As the comparison between acquired firms and the control group of non-acquired firms remains vulnerable to the presence of nonrandom sample selection, we use matching to select pairs of firms with similar observable characteristics and pre-treatment trends prior to the change in ownership. For the inference of causal effects of acquisition to be considered valid, we require the assumption that, conditional on the observable characteristics that are relevant for the acquisition decision, the potential outcomes of interest for the treated and non-treated firms are orthogonal to acquisition.

To construct our control group of non-acquired firms we begin by estimating a model for the probability of being acquired. ${ }^{18} \mathrm{We}$ use a probit model where we regress a dummy variable indicator of whether the firm becomes acquired during the sample period on various innovation inputs, controlling simultaneously for a number of other factors that potentially influence this probability (described in $\left.X_{i t-1}\right) .{ }^{19}$ Formally,

$$
\text { Acquisition }_{i t}=\left\{\begin{array}{l}
1 \text { if } \sigma+X_{i t-1}^{\prime} \rho+d_{t}+\xi_{i t}>0 \\
0 \text { if } \sigma+X_{i t-1}^{\prime} \rho+d_{t}+\xi_{i t} \leq 0
\end{array}\right.
$$

In equation (1), Acquisition $_{i t}$ is a dummy variable that takes the value one if there is a change from domestic to foreign ownership in period $t$. The vector $X_{i t-1}^{\prime}$ reflects pre-treatment firm characteristics that influence acquisition, $d_{t}$ denotes time dummies, and $\xi_{i t}$ is the error term, which we assume is normally distributed with variance $\sigma_{z}^{2}$. In all regressions we use cluster robust standard errors. The results are reported in Table 2.

Amongst the observable characteristics we follow Chen (2011) and include a measure of labour productivity (measured as sales per employee), physical investment per employee, sales growth and firm size (employees, measured in various size-bands). ${ }^{20}$ In addition we consider how acquisition depends on pre-acquisition differences in $R \& D$ expenditures. In Table 2 column (i) we include the logarithm of total innovation expenditures and a measure of innovation intensity (total innovation expenditures/turnover). In column (ii) we add the ratio of expenditures on external to internal $R \& D$,

\footnotetext{
${ }^{18}$ Rosenbaum and Rubin (1985) show that if conditioning on X makes the non-participation outcome independent of the treatment status it is also independent when conditioning on $\mathrm{P}(\mathrm{X})$.

${ }^{19}$ We use a pooled cross-sectional approach. The results also hold if we use a random effect probit model.

${ }^{20}$ Arnold and Javorcik (2009), Harris and Robinson (2002), Balsvik and Haller (2010) and Guadalupe et al. (2012) have also shown that foreign MNEs are more likely to select domestic firms that are more productive and larger.
} 
along with two measures of expenditures of $R \& D$ expenditures from within the same business group. These are a dummy variable if these latter expenditures are non-zero, which we use to capture whether being a MNE (in R\&D) matters or not for acquisition, and their ratio over total external R\&D spending, which captures the extent to which this source of knowledge is used. In column (iii) we separate the measure of total innovation expenditures into external and internal R\&D expenditures, while in column (iv) we drop the variable measuring the ratio of expenditures on external R\&D from the same business group over total external R\&D expenditure. We use columns (v) and (vi) to allow for differences in the types of firms that are acquired by frontier versus non-frontier firms and in column (vii) we test whether these differences are statistically significant. In all of the regressions we include year and industry dummies (measured at the two-digit level).

The results from Table 2 indicate that firms acquired by foreign MNEs are fundamentally different from non-acquired firms in Spain, with strong evidence of cherry-picking when measured by R\&D and non-R\&D characteristics. Focusing on the $R \& D$ variables the results indicate that foreign owned firms target Spanish firms that have greater internal R\&D expenditures or are international in their R\&D. While we find some suggestive evidence that there may also be differences in the type of firms acquired by MNEs at the technological frontier from those that lie behind, these differences are not statistically significant (Table 2 columns (v) to (vii)).

Based on the results from equation (1), we pair each acquired firm with the closest non-acquired firm in the same industry and year (excluding those from the same Spanish region) by caliper matching with replacement. ${ }^{21}$ Our results are robust to alternative matching procedures based on nearest neighbour and propensity score reweighting. We present the regressions with the alternative matching procedures in the On-line Appendix B. We include as controls for the probit specification those in column (iv) of Table 2.

A crucial assumption in our estimation strategy is that foreign acquisition does not generate spillovers on non-acquired firms (SUTVA assumption). We initially rule out this possibility, and relax this assumption in section $5 .^{22}$ The matching procedure works well for all variables and any sample of firms (see Table 3) implying that control and treatment groups are equivalent in their observable characteristics before acquisition for the different samples. ${ }^{23}$

\footnotetext{
${ }^{21}$ Matching is carried out with STATA command PSMATCH2 by Leuven and Sianesi (2003). The caliper used is equal to 0.001 .

${ }^{22}$ As in Girma et al. (2015) we assume that spillovers are concentrated within regions. This extends the more typical approach in the literature, which is to exclude the possibility of matches outside of the same industry and year (see for example Javorcik and Poelhekke (2017).

${ }^{23}$ The balancing assumption also holds when we separate firms into frontier and non-frontier acquisitions.
} 


\section{The Effects of Foreign Acquisitions on R\&D}

\subsection{Does Foreign Acquisition Increase the Likelihood the host's R\&D Labs are Shut?}

We begin by examining econometrically the probability that the affiliate will cease $R \& D$ following its acquisition by estimating a probit model and a Cox proportional hazard model. ${ }^{24}$ The probability that a firm ceases R\&D in year $t$ can be expressed as follows:

$$
S_{i t}^{*}=\pi+\zeta A c q_{i t-1}+\epsilon_{i t}, \quad S_{i t}=1 \text { if } S_{i t}^{*}>0 \text { and zero otherwise. }
$$

Where $S_{i t}^{*}$ is a latent variable and $S_{i t}$ is the observed binary variable that takes the value one if the firm ceases internal R\&D expenditures and zero otherwise. The indicator $A c q_{i t-1}$ takes the value one if the firm has been acquired by a foreign MNE in period $t-1$. If acquisition increases the probability of stopping $\mathrm{R} \& \mathrm{D}$ we expect $\zeta>0$. In the above specification $\epsilon_{i t}$ is the error term. Using the probit model we test whether acquisition affects the probability a firm will no longer undertake R\&D. We next allow for the censoring of the observations by estimating a Cox proportional hazard model. This model assumes that the observed fraction of firms that cease internal R\&D expenditures in year $t$, relative to those that do not stop at year $t$ is:

$$
h(t)=h_{0}(t) * \exp \left\{\eta A c q_{i t-1}\right\}
$$

where $h_{0}(t)$ is the baseline hazard of stopping internal R\&D. A parameter value for $\eta$ larger than one implies that acquisition is associated with an increased likelihood that $\mathrm{R} \& \mathrm{D}$ expenditures will end for acquired firms.

In Table 4, we present formal evidence of the effect of foreign acquisition on the probability of stopping for the matched sample. In panel A, we show the estimations using a probit model. In panel $\mathrm{B}$, we report the Cox proportional hazard estimates (we report the hazard ratios). Column (i) shows the effect of acquisition not distinguishing between the effects of location of the headquarters of the acquiring MNEs and column (ii) separates acquisitions that occur from countries technologically leading countries (Germany, Japan and the USA) and those from non-frontier countries.

The results in panel A column (i) indicate that foreign acquisition increases the probability of stopping domestic R\&D by 12.2 percentage points. Column (ii) shows that this effect is larger when acquisitions are from frontier countries (16.8 percentage points) than from non-frontier countries (13.7 percentage points). A concern with the probit model is that it does not account for the censoring of the

\footnotetext{
${ }^{24}$ The results are identical when using a linear probability model.
} 
data. To account for this in panel B, we present the results using the Cox proportional hazard estimates. Column (i) shows that acquired firms are statistically more likely to shut their R\&D facilities than domestic firms with similar pre-acquisition characteristics. Once we distinguish between firms acquired by frontier or non-frontier countries, we observe that the effect is due to acquisition by MNEs from frontier countries. Compared to the matched sample of firms, acquisition by frontier MNEs significantly increases the risk of stopping internal $R \& D$ expenditures in the year of the acquisition. Moreover the effect is large; the risk of stopping is 0.639 times higher after acquisition from frontier MNEs as compared to non-acquired firms. This is supportive of an argument that the opportunity cost of innovating within the subsidiary versus elsewhere in the MNE is highest for technologically leading MNEs and therefore these firms are more likely to choose an R\&D structure that shuts these labs. This might occur because the remaining R\&D labs of the MNE are at the knowledge frontier and there is little additional knowledge that can be acquired from the domestic market.

\subsection{Does Acquisition Affect R\&D Expenditures and Employment?}

In the first three columns in Table 5 we report the effects of acquisition-FDI on total innovation expenditures (logged), along with the share of total domestic R\&D expenditures undertaken within the firm (internal $R \& D /$ total $R \& D$ ), and the share of total expenditures on $R \& D$ services produced outside of the firm (external $R \& D /$ total $R \& D$ ). In the remainder of the table we consider how the share of total external R\&D spending evolves post-acquisition compared to the matched counterfactual of firms; where this includes the share of purchases of $R \& D$ from other domestic firms (external domestic $R \& D /$ total $R \& D$ ) and imported knowledge (external foreign $R \& D /$ total $R \& D$ ). Finally, we separate external foreign $R \& D$ further into knowledge imported within the same business group, denoted $R \& D$ technology transfers. To understand whether acquisition also leads to changes in the types of workers employed in R\&D we consider the education background of R\&D employees (reported in Table 6). All of the regressions have the standard difference-in-difference form set out in equation (4) estimated on the matched sample of firms that remain $R \& D$ active:

$$
\begin{aligned}
Y_{i t}= & \kappa_{1} A c q_{i t} * f_{i}+\kappa_{2} A c q_{i t-1} * f_{i}+\kappa_{3} A c q_{i t-2} * f_{i}+\varrho_{1} A c q_{i t} * n f_{i}+\varrho_{2} A c q_{i t-1} * n f_{i}+ \\
& +\varrho_{3} A c q_{i t-2} * n f_{i}+\tau_{i}+d_{t}+v_{i t}
\end{aligned}
$$


where $Y_{i t}$ represents different elements of the knowledge production function (various measures of innovative expenditures levels, expenditure shares and types of R\&D workers). ${ }^{25}$ For ease of exposition, we present results differentiating between acquisitions by frontier $\left(f_{i}\right)$ and non-frontier MNEs $\left(n f_{i}\right)$. The coefficients of interest are $\kappa_{1}, \kappa_{2}$ and $\kappa_{3}$ which measure the post-acquisition change in $Y$ for the treatment group when acquisition is by a technologically frontier MNE, where we allow this effect to differ in the year of acquisition versus one-year and two-years later. The coefficients $\varrho_{1}, \varrho_{2}$, and $\varrho_{3}$ capture the effect of acquisition by a non-technologically frontier MNE. Our counterfactual are non-acquired firms. Time-dummies are denoted by $d_{t}$ and capture the effects of any common-shocks that affect both the treatment and the control group together, a set of firm-fixed effects is denoted by $\tau_{\mathrm{i}}$, while $v_{i t}$ is the error term. In all regressions, we include industry-specific time trends and year dummies. The regression is estimated using robust variance-covariance matrix estimators with clustering at the industry level.

From the results presented in Table 5 it is evident that the changes in $R \& D$ expenditures after acquisition are different when acquisition occurs from a frontier MNE than when acquisition is from a non-frontier MNE. Total innovation expenditures increase by $14.8 \%$ in the year of the acquisition compared to the control group, and by $94 \%$ two years following acquisition (column i) when acquisition is by a frontier MNE. In contrast when acquisition is from a non-frontier MNE total innovation spending falls; by $28.6 \%$ in the year of acquisition and by $23.5 \%$ one year later. The existing literature has reported rather mixed outcomes from acquisition-FDI on total R\&D spending. For example, Stiebale and Reize (2011) find falls in R\&D spending, whereas Bertrand (2009), Bertrand et al. (2012) and Bandick et al. (2014) report increases. The type of heterogeneity we consider, how close the acquirer is to the technological frontier, could represent one explanation for these differences.

Total innovation expenditure is the sum of $R \& D$ expenditures within the firm, along with $R \& D$ services purchased from external R\&D labs, universities etc., where these may be either domestic or foreign. It also includes non-R\&D types of spending such as training, product development and marketing. The results presented in column (ii) suggest that the share of total R\&D spending on internal $\mathrm{R} \& \mathrm{D}$, which is made up largely of expenditures on the scientists, engineers and their support differ markedly post-acquisition to this total innovation spending. When acquisition occurs from a frontier$\mathrm{MNE}$, the share of spending on internal $\mathrm{R} \& \mathrm{D}$ expenditures declines in the post-acquisition time period relative to the counterfactual (by $7.0 \%$ in the year of acquisition and by $8.3 \%$ one year later). Again,

\footnotetext{
${ }^{25}$ Total R\&D and employment are logged values.
} 
in contrast, they remain constant from a statistical perspective when acquisition was by a non-frontier MNEs, even though total innovation spending for this group fell on average post-acquisition. To aid with the interpretation of these changes in expenditure shares we also extract their impact on the level of spending. The results imply that for acquisitions from frontier countries, internal R\&D expenditures rise by $3.9 \%$ in the year of the acquisition. They then decline by $14.3 \%$ one year after and increase by $157.0 \%$ two years after acquisition. For non-frontier MNEs, given that there is no effect in the ratio of internal $R \& D$ to total $R \& D$ expenditures (column ii), the change in internal $R \& D$ is proportional to that for total R\&D expenditures. This implies that for acquisitions from non-frontier countries internal R\&D expenditures decline by $24.9 \%$ in the year of acquisition, and by $20.9 \%$ the next year.

For acquisitions by frontier MNEs the decline in the share of internal R\&D spending in total R\&D spending along with the rise in total innovation spending is explained by an increase in expenditures on R\&D services provided outside of the firm and in particular by $R \& D$ technology transfers. For nonfrontier acquisitions we find no evidence of such transfers. ${ }^{26}$ That the share of R\&D technology transfers in total spending rises following acquisition indicates the sharing of technical information between the various R\&D labs that the MNE operates. Such evidence helps to explain why MNEs have been found to use more intensively external sources of knowledge in the cross-section evidence of Veugelers and Cassiman (2004) and Criscuolo et al. (2010). Our evidence suggests a causal effect of acquisition on knowledge transfers from abroad. This is also consistent with very recent evidence of productivity declines following disinvestment in Javorcik and Poelhekke (2017). They argue that foreign ownership benefits acquired firms due to a constant inflow of knowledge of the type we report.

Within the category of internal R\&D much of the expenditures are made up of staff costs. Table 6 shows what happens to skill mix of employment in R\&D. We again observe that there are again some differences between acquirers relative to the counterfactual. For acquisitions from frontier countries there is an increase in the employment of workers with Ph.D. level training (by $7.8 \%$ on the year of the acquisition). The remaining employment categories remain constant. When acquisition is by an MNE from a non-frontier country, the number of employees with the 5-year BA degree declines by $25.6 \%$ the year of acquisition and by $23.1 \%$ one year after acquisition. There are no other changes to the employment mix. These results are supportive of the idea of skilled bias technology but only for acquisitions by frontier MNEs.

${ }^{26}$ Total innovation spending falls for this group in column (i) because of a decline in non-R\&D spending. 


\subsection{Does Acquisition Affect Successful Innovation?}

In previous sections, we have shown that when acquisition is from a frontier MNE, acquisition decreases domestic innovation expenditures, increases technology transfers and there is some reallocation of $R \& D$ budgets towards high-skilled workers. Do these changes make the firms more efficient at generating innovation output? In this sub-section, we explore the effect of acquisition on innovation output using information on the number of patents applied by the firm. We follow the same econometric specification set out in equation (4).

In Table 7 column (i) we report our estimates for the effect of acquisition on the number of patents as a ratio of innovation expenditures, where the former are measured for a three year period following acquisition. ${ }^{27}$ From this regression, we find that acquisition has a positive effect on the efficiency with which patents are generated when the acquiring MNE is from a frontier country. For non-frontier acquisitions we find a negative effect similar to Stiebale (2016), although it is not statistically significant.

In Table 7 columns (ii) and (iii), we account for the fact that not all innovations are patented by examining the effect of foreign acquisition on product and process innovation. Here we find some differences according to the type of innovation. The results suggest a positive effect on process innovation when acquisitions are from frontier MNEs. Similar to Guadalupe et al. (2012), we find no significant effect for product innovation.

Finally, to take into account the market channel stressed by Guadalupe et al. (2012), we refine our analysis by including (the log of) exports as a control variable. The results of the estimates are presented in columns (iv) to (vi) of Table 7 for patents, product and process innovations respectively. These estimations confirm the findings from previous regressions: acquisition from frontier countries has a positive effect on patent efficiency and process innovation. Of interest, they also indicate a positive and significant effect for exports, confirming that access to a larger market also increases the inventiveness of the subsidiary. These results suggest that acquisition-FDI may increase domestic innovation through a number of alternative channels.

\subsection{What is the Aggregate effect of Acquisition-FDI on the Domestically Produced Knowledge} Stock?

\footnotetext{
${ }^{27}$ As in previous regressions in this subsection, we control by firm fixed effects, industry-specific time trends and year dummies
} 
To understand how acquisition-FDI impacts collectively on the efficiency of aggregate domestic knowledge production, we construct an index for the growth of Spanish patents per euro of expenditure. At a particular point in time the innovation index is measured as the weighted average of innovation by individual firms. Denoting by $P_{t}$ the aggregate index of technology (in terms of patents) in a country in year $\mathrm{t}$ and $\Delta \mathrm{P}$ the change in the index of technology, the effect of acquisition on the change in the aggregate index can be expressed as the ratio $\frac{\Delta P^{A c q}}{\Delta \mathrm{P}}$, where $\Delta P^{A c q}$ is the estimated effect of acquisition by MNEs from frontier and non-frontier countries as follows:

$$
\begin{aligned}
\Delta P^{A c q}= & \sum_{i=1}^{N} S_{i t} P_{i t}-\sum_{i=1}^{N} S_{i 0} P_{i 0}=\sum_{i=1}^{N} S_{i 0}\left(P_{i t}-P_{i 0}\right)+\sum_{i=1}^{N} P_{i 0}\left(S_{i t}-S_{i 0}\right)+ \\
& \sum_{i=1}^{N}\left(P_{i t}-P_{i 0}\right)\left(S_{i t}-S_{i 0}\right)-\sum_{i \in \text { exit }}^{N} S_{i t}^{\text {exit }}\left(P_{i 0}-\bar{P}\right)+\sum_{i \in \text { entry }} S_{i t}^{\text {entry }}\left(P_{\text {ientry }}-\bar{P}\right),
\end{aligned}
$$

where the variables $P_{i 0}$ and $S_{i 0}$ represent the patents and the weights of acquired firms respectively before acquisition, $P_{i t}$ and $S_{i t}$ are the estimated patents and weights of acquired firms after acquisition, $P_{\text {ientry }}$ are patents by firms that start R\&D after acquisition and $\bar{P}$ is the average number of patents in the economy.

The first part of the decomposition represents the within firm element and measures the change in patents keeping constant the weights used in the construction of the index: $\sum_{i=1}^{N} S_{i 0}\left(P_{i t-} P_{i 0}\right)=$ $\sum_{i \in f} S_{i 0}\left(\varphi^{f} P_{i 0}\right)+\sum_{i \in n f} S_{i 0}\left(\varphi^{n f} P_{i 0}\right)$, where $f$ means acquisition from frontier country and $n f$ is acquisition from non-frontier country In this expression $\varphi^{f}$ and $\varphi^{n f}$ are transformations of the estimated coefficients of acquisition on patents for frontier and non-frontier acquirers in Table 7 column (i).

The second component is labelled the between effect, and measures the change in firm-weights keeping constant patents: $\sum_{i=1}^{N} P_{i 0}\left(S_{i t}-S_{i 0}\right)=\sum_{i \in f} P_{i 0}\left(S_{i t}-S_{i 0}\right)+\sum_{i \in n f} P_{i 0}\left(S_{i t}-S_{i 0}\right)$. The weights after acquisition are the estimated values calculated as follows: $S_{i t}=\frac{N_{i 0}\left(1+\varpi^{f} D^{f}+\varpi^{n f} D^{n f}\right)}{\sum_{i=1}^{N} N_{i 0}\left(1+\varpi^{f} D^{f}+\varpi^{n f} D^{n f}\right)}$. The value $N_{i 0}$ is either total innovation expenditures or internal R\&D expenditures depending which weights we use. The expressions $\varpi^{f}$ and $\varpi^{n f}$ are transformations of the estimated coefficients of acquisition on total innovation expenditures and internal $R \& D$ expenditures respectively for frontier 
and non-frontier acquirers in Table 6 (columns (i) and (ii)). We calculate the average of the significant coefficient estimates for frontier and non-frontier countries to construct $\varpi^{f}$ and $\varpi^{n f}$. The expressions $D^{f}$ and $D^{n f}$ are indicators of whether a firm has been acquired by a frontier or a non-frontier foreign firm respectively.

The third element of the decomposition is the cross effect. This effect measures the correlation between the change in patents and weights. The cross term typically does not have an important economic impact and it is usually very small.

The exit effect is calculated as in the following expression $\sum_{i \in e x i t} S_{i t}^{\text {exit }}\left(P_{i 0}-\bar{P}\right)=$ $\sum_{i \in \text { exit \& } f} S_{i t}^{\text {exit }}\left(P_{i 0}-\bar{P}\right)+\sum_{i \in \text { exit } \& n f} S_{i t}^{\text {exit }}\left(P_{i 0}-\bar{P}\right)$. The predicted weights are calculated as $S_{i t}^{\text {exit }}=\frac{N_{i 0}\left(1++D^{n f}\right)}{\sum_{i=1}^{N} N_{i 0}\left(1+\varrho^{f}+\varrho^{n f} D^{n f}\right)}$. In these weights, the expressions $\varrho^{f}$ and $\varrho^{n f}$ are the estimated coefficients on the effect of acquisition on the probability of exit for frontier and non-frontier acquisitions from the probit model in Table 4 panel A column (ii).

The last component is the entry effect: $\sum_{i \in e n t r y} S_{i t}^{\text {entry }}\left(P_{\text {ientry }}-\bar{P}\right)$. In comparison to the rate at which acquired firms stop $R \& D$, starting $R \& D$ occurs very infrequently. There are 8 firms in the dataset that are acquired by a foreign firm and then begin $R \& D$. We investigated whether acquisition FDI is associated with a higher or lower probability of starting $R \& D$ and find no statistically significant effect. Given the low power of a regression with so few examples of starting R\&D post-acquisition we report this in Table A2 in the On-line Appendix A and do not formally include it within our construction of the index. Finally, as in Bloom et al. (2015) in order to obtain the denominator of the ratio $\frac{\Delta P^{A c q}}{\Delta \mathrm{P}}$, we use the aggregate growth of patents for the period 2004-2009. This value is equal to $7.7 \%$ for the Spanish patents.

The results of this exercise are reported in Table 8. In column (i) we use internal R\&D to weight firms and in column (ii) we use total innovation expenditures as weights. ${ }^{28}$ As a reminder internal innovation spending in the data includes R\&D spending that occurs internally to the firm within Spain. Total innovation spending additionally includes R\&D resources that are purchased from outside of the firm, both elsewhere in Spain and from abroad, including those from other parts of the same business group. To demonstrate the importance of including these external R\&D expenditures, including technology transfers from the parent, we report the results from this aggregation exercise without these

\footnotetext{
${ }^{28}$ As an alternative we also using total employment in R\&D as weights. These results, not reported, are very similar to those for internal R\&D expenditures.
} 
expenditures in column (i) and with them in column (ii). We also separate the within-firm, betweenfirm and exit effects according to whether the acquisition is from a technologically frontier or nonfrontier country.

Both the choice of weights and the technology sophistication of the acquirer matters for the change in the domestic technology index, with the choice of weights particularly important for the overall effect. In both columns (i) and (ii) the total effect of acquisition-FDI on the technology index is positive. In the first column acquisition FDI increases Spanish technology by $6.45 \%$ for the sample period, whereas in column (ii) acquisition-FDI increases the Spanish technology index by $7.14 \%$. The difference between columns is explained by the differential effect on the relative size of the domestic R\&D lab that occurs following acquisition by foreign MNEs (the weights used in the index): the between component is smaller when we consider internal $\mathrm{R} \& \mathrm{D}$ as weights rather than weights based on total R\&D . Moreover, there is a positive effect from the closure of $R \& D$ labs following acquisition, although this effect is small in magnitude, and an improvement in the inventiveness of acquired firms (the within effect is positive). In column (ii) the results for the within, between and cross effect are larger than in column (i). This highlights that simply focusing on domestic R\&D expenditures misses an important component of the benefits of acquisition-FDI on the domestic production of knowledge. Technology transfers increase the value of $R \& D$ conduced within the acquired affiliate. In both columns the majority of the effect comes from the changes that occur when acquisition is from a technologically leading country. Taken together, our results suggest that acquisition-FDI enhances the domestic innovation.

Given that we found a positive impact of foreign acquisition on process innovation, for completeness we replicate previous calculations using process innovations as the measure of the Spanish innovation stock. We present the results in columns (iii) and (iv) of Table 8. We assume that the average growth of process innovations for the period 2004-2009 is equal to the sample mean of our dataset. We find that the overall effect of acquisition-FDI on the domestically produced process innovation stock is positive. The effect is equal to $0.45 \%$ when our weights are in terms of internal $\mathrm{R} \& \mathrm{D}$ (in column (iii)) and $1.15 \%$ when the weights are in terms of total innovation expenditures (in column (iv)). Overall, the calculated impacts are smaller when we use process innovations instead of patents as the measure of innovation output. The main reason for this difference is that the overall growth of the technological index (the denominator $\Delta \mathrm{P}$ ) is larger for process innovations than for patents. 


\section{Robustness}

\subsection{Alternative Definitions of Technological Frontier Countries}

Within our analysis we consider MNEs from Japan, USA and Germany as countries that are likely to lie at the technological frontier. ${ }^{29}$ While the empirical results we present suggests that this assumption is a reasonable partitioning of the acquisitions that take place in the data, in Table 9, we test the sensitivity of our results by choosing an alternative definition. For this new measure we combine country and industry $R \& D$ intensity together ( $\& \& D$ expenditures over value added) using information made available from the STAN database from the OECD. We identify frontier acquisitions if the MNE is from a country that is above the $90^{\text {th }}$ percentile of R\&D spending within each industry. ${ }^{30}$ Under this new measure, there are 10 acquisitions from the US within industries in which MNEs from that country are considered to lie at the frontier, 7 from the France and the Netherlands, 4 from Germany, Japan and Sweden, 3 from Denmark and 1 from the UK, giving a total of 40. Given the large number of outcome variables we discuss in the paper we focus the results only on the main variables of interest.

In column (i) of Table 9 we present a regression that analyses the probability internal $R \& D$ will cease for this alternative definition of frontier MNEs. Comparing the results with those in Table 4 we note that qualitatively they do not change. We continue to find evidence of an increase in the probability of stopping R\&D for firms acquired by MNEs from technologically advanced countries.

In columns (ii) to (iv) we report results for total innovation expenditures, internal $R \& D$ and technology transfers as a share of total $R \& D$ spending. The results showed in this Table are again highly supportive of those using an alternative definition of frontier. In column (ii) we find a significant increase in total innovation expenditures, in column (iii) a reduction in the share of internal expenditures and in column (iv), an increase in the share of international technology transfers for firms acquired by MNEs at the technological frontier.

The effects of acquisition on different the employment of workers with the highest education levels are reported in column (v) of Table 9. These results consistently suggest that the average quality of workers increases after acquisition for frontier MNEs. Finally, in column (vi) we display results for

\footnotetext{
${ }^{29}$ Estimating the changes in R\&D expenditures shares separately for acquisitions from Germany, Japan and the US separately suggests that the technology transfers within the firm in column (viii) are largely explained by the FDI from Germany and the US. We find weaker evidence of the same effect for Japan, although we note there are only 6 acquisitions from here in the data period.

${ }^{30}$ We have also tested the robustness of our results to a definition of frontier MNEs based on the 10 countries with the highest ratio of Business Enterprise R\&D expenditures (BERD) over GDP for the period 2004-2009 and the countryindustry classification described but using the $95^{\text {th }}$ percentile of $R \& D$ spending within each industry to define the frontier.
} 
innovation output. The results in this table are again similar to those already presented in Table 7 . We find a positive effect of foreign acquisition on patenting, where again this effect is significant only for acquisitions by MNEs from countries at the technological frontier.

\subsection{Pre-existing trends}

The difference-in-differences method that underlies our estimations rests on the assumption that the treatment and the control group share statistically similar pre-treatment trends. We perform additional tests control for pre-existing trends in two ways. First, we conduct a matching exercise which now includes two years of pre-treatment data and second we conduct a placebo test, bringing forward the date of acquisition into the pre-treatment period and studying the behaviour of R\&D over this period.

For the alternative matching, where we add two years of pre-treatment data, we find results that closely align with those reported previously. Again, we focus on the main outcomes of interest. The results are reported in Table 10. We find that the probability of stopping R\&D (column (i)) is more likely when acquisitions is from an MNE at the technological frontier but, if they remain R\&D active, there is an increase in total innovation expenditures (column (ii)) and a shift towards technology transfers (column (iv)). We also find skill-upgrading (column (v)) and increases in the rate of patenting for these firms (column (vi)).

In Table 11, we present our placebo-type test, where we regress one and two leads of the acquisition variables on the dependent variables. The results from these placebo regressions are very different from previous estimations. As expected, we now find no differences between control and treatment groups in terms of the probability of quitting R\&D (column (i)), as well as R\&D expenditures and R\&D personnel in columns (ii) to (v) and innovation output in column (vi). These results point strongly to a conclusion that the treatment and control group share similar pre-treatment trends in terms of observable characteristics.

\subsection{Indirect effects: Results controlling by Stable Unit Treatment Value Assumption (SUTVA) violation}

Thus far, our calculations of the effects of acquisition-FDI preclude the possibility that there may exist indirect effects from FDI to non-acquired domestic firms. The literature has discussed several types of indirect effects (Bloom et al., 2016). A first type includes product market rivalry or business 
stealing effects. In theoretical models the net effect is ambiguous as they depend on whether the products of the firms are strategic complements or substitutes. In case of product market rivalry there can be an increase in the R\&D investment of the rival firm because the marginal profitability of the rival firm increases, while under the business stealing effects there is a decrease (Bloom et al., 2016). These effects might be moderated by the observability of the $R \& D$ investments of the acquired firm (Denicolò and Polo, 2018a; Lopez and Vives, forthcoming). A second type of indirect effect are those that arise due to technological spillovers. If there are knowledge transfers from the foreign MNE to the acquired firm, non-acquired firms may also be able to learn of these new technologies, for example through the information available in the patents or mobility of workers (Balsvik, 2011). As a consequence, non-acquired firms might have incentives to increase their own R\&D expenditures. ${ }^{31}$ Given that we find that acquisition-FDI leads to reduced domestic expenditures in some cases, but greater technology transfers, these indirect might plausibly be positive or negative.

We estimate the combined direct and indirect effects using the methodology proposed by Girma et al. (2015), which they apply to the effects of acquisition-FDI on productivity. ${ }^{32}$ The approach by Girma et al. (2015) considers that there are $r=1, \ldots R$ industry-region clusters such that SUTVA holds across clusters but not necessarily within clusters. Calling $y^{d}$ the outcome variable (R\&D expenditures and $\mathrm{R} \& \mathrm{D}$ employment) with $d=1$ if a firm is foreign acquired and $d=0$ if not, the average potential outcomes, denoted by $\bar{y}_{p}^{d}$, are a function of the proportion $p$ of treated individuals in a given cluster. For a given level of foreign acquisitions $p$, there are four causal treatment effects: a) The direct causal effect of the treatment is equal to $\bar{\gamma}_{p p}^{10}=\bar{\gamma}_{p}^{1}-\bar{\gamma}_{p}^{0}$. This is the difference in the outcome variable between foreign acquired and non-acquired firms for a given level of foreign acquisition in a cluster; b) the indirect effect on the non-treatment is equal to $\bar{\gamma}_{p 0}^{00}=\bar{\gamma}_{p}^{0}-\bar{\gamma}_{0}^{0}$. This is the difference in the outcome variable between a non-acquired firm in a cluster with $p$ foreign acquisitions and a nonacquired firm in a cluster with zero foreign acquisitions; $c$ ) the total treatment effect is equal to $\bar{\gamma}_{p 0}^{10}=$ $\bar{\gamma}_{p}^{1}-\bar{\gamma}_{0}^{0}$. This is the sum of the direct and indirect effect and it measures the difference in the outcome variable between acquired firms in a cluster with $p$ foreign acquisitions and a non-acquired firms in a cluster with zero foreign acquisitions and d) the marginal treatment effect on the treated is $\bar{\gamma}_{p 0}^{11}=\bar{\gamma}_{p}^{1}-$

\footnotetext{
${ }^{31}$ For a summary of the effects of R\&D on non-merged firms see Denicolò and Polo (2018) and Jullien and Lefouili (2018).

32 There may of course be further general equilibrium effects on domestic technology production as a results of acquisitionFDI that occur through price and quantity changes in other markets, in particular in the labour market. Our data sources do not contain the information necessary to investigate these changes. As the full extent of these general equilibrium changes are likely to take some time to fully realise themselves, we arguably capture the most important short-run changes.
} 
$\bar{\gamma}_{0}^{1}$. This is the difference in the outcome variable for the acquired firms if the proportion of foreign acquisitions would drop from $p$ to zero.

In our analysis, we establish 32 industry-region clusters with an average of $0.7 \%$ foreign acquisitions. As the methodology relies of a sufficient number of acquisitions within each cluster we cannot distinguish between types of acquisitions in this part of our analysis. The methodology consists of two steps: In the first step, we calculate average potential outcomes per each cluster controlling by selection into acquisition. In order to do this, for each cluster, first, we calculate a propensity score of being acquired based on firm characteristics given by $X .{ }^{33}$ Second, we calculate an outcome equation (where the outcomes are R\&D expenditures and employment) using an inverse probability weighted regression, as follows: $y_{i r}=\alpha+\beta d_{i r}+\delta X+$ error, where $i=1, \ldots N$ denotes the number of firms in the cluster. Third, we compute potential outcomes for treated and non-treated as in the following expression: $\bar{y}_{r}^{d}=1 / N \sum_{i=1}^{N} \tilde{\alpha}+d \tilde{\beta}+\tilde{\delta} X$ with $d=0,1$. In the second step, we calculate treatment effects. In this part of the analysis, we consider the average potential outcomes as the outcome variable and the proportion of acquired firms as the treatment variable. We control for selection by conditioning on a generalised propensity score (GPS) via a fractional logit model, where the pre-treatment cluster characteristics denoted by $Z$ are based on Girma et al. (2015) and include exports, average financial constraints, labour productivity, average size, internal R\&D, physical investment, and sales growth. Let $\tilde{\lambda}$ denote the vector of estimated coefficients, and $T=\frac{e^{z \tilde{\lambda}}}{1+e^{Z \tilde{\lambda}}}$ then the GPS conditional on $Z$ and on $p_{r}$ is equal to $\tilde{G}_{r}=[\mathrm{T}]^{p_{r}}[1-\mathrm{T}]^{1-p_{r}}$. We calculate cluster level potential outcomes using the following polynomial approximation: $E\left[y_{r}^{d} \mid \tilde{G}_{r}, p_{r}\right]=\beta_{0}+\beta_{1} \tilde{G}_{r}+\beta_{2} p_{r}+\beta_{3} \tilde{G}_{r}^{2}+\beta_{4} p_{r}^{2}+\beta_{5} \tilde{G}_{r} p_{r} \cdot{ }^{34}$

In figure 1, we plot the estimated direct, indirect, total and marginal treatment effect on total innovation expenditures evaluated at the mean proportion of foreign acquisition. We also include the $90 \%$ confidence interval. The direct average effect is positive statistically significant and equal to 0.48 , suggesting that foreign acquired firms in cluster with average foreign acquisitions have $48 \%$ greater expenditures on total R\&D than non-acquired firms. The indirect effect is also positive but it is not significant at standard levels (the error bounds include zero). The total effect is significantly positive and slightly larger than the direct effect. Finally, the marginal effect is not significantly different from zero. For this measure of innovation our results therefore do not suggest strong spillovers.

\footnotetext{
${ }^{33}$ We include as pre-treatment firm variables: labour productivity, size, internal and external R\&D expenditures, physical investments and a dummy variable equal to one if the plant had overseas R\&D facilities.

${ }^{34}$ We thank Sourafel Girma for sharing the program for the calculation of the treatment effects. The pre-treatment cluster variables are similar to Girma et al. (2015) and they include exports, average financial constraints, labour productivity, average size, internal R\&D, physical investment, and sales growth.
} 
In figure 2, we show the effects for disaggregated $R \& D$ expenditures (internal, external, external domestic and technology transfers). The result suggest that foreign acquisition has a positive direct effect on internal R\&D expenditures, as we found in the matching regressions in the previous section. The indirect effect is again positive but it not significant at standard levels. The total effect is positive and slightly larger than the direct effect. For external expenditures, we find a negative and statistically significant direct effect and a positive and significant indirect effect. This suggests that acquired firms tend to reduce their dependence to external technological providers while non-acquired firms increasingly buy $R \& D$ from external providers moving towards a more hybrid R\&D structure. Finally, we do not find significant evidence of either direct or indirect effects from foreign acquisitions on technology transfers when we do not account for the origin of the MNE.

In the first panel of figure 3, we plot the estimated effects and the $90 \%$ confidence interval for total employees in $R \& D$. The direct average effect is positive suggesting that foreign acquired firms have larger R\&D employment than non-acquired firms. The indirect effect is also positive but it is not significant at standard levels. The total effect is significantly positive and slightly larger than the direct effect. This suggests that there might be a positive spillover effect on the R\&D employment of domestic firms but it is imprecisely estimated. The estimated coefficient of the total effect is equal to 0.9. This implies that the number of employees working in R\&D in a foreign firm in a cluster with average foreign acquisitions is $90 \%$ higher than the R\&D employment of a non-acquired domestic firm in a cluster with no foreign acquisitions. We interpret this change cautiously given that $R \& D$ employment for the control group is very small. Finally, the marginal effect is not significantly different from zero.

In the second panel of figure 3, we plot the effects for $\mathrm{R} \& \mathrm{D}$ employment with a $\mathrm{PhD}$. In this case, the total effect is positive and larger than the direct effect, which is also positive. This suggests that there is a positive direct effect of acquisition on the $R \& D$ employment with the highest education levels and an indirect positive effect on non-acquired firms. ${ }^{35} \mathrm{We}$ also find some suggestive evidence of a positive spillovers but again those effects are not statistically significant at standard levels.

From this exercise, we conclude that the direct effects we focus on in Section 4 are the most important changes that occur to the economy following acquisition. They also confirm that spillover effects may be present and therefore careful consideration of what represents a valid counterfactual is

\footnotetext{
${ }^{35} \mathrm{We}$ do not find any statistically significant effect of acquisition on any other type of employment with the exception of a positive direct effect on workers without higher education. Taking this evidence together, these results suggest that there are no significant externalities for R\&D employment with 5-year undergraduate degree or lower educational levels.
} 
warranted when studying the effects on R\&D. Finally, as the spillovers we uncover are largely positive, they imply that our estimates of the direct effects are, if anything, a lower bound on the R\&D effects of acquisition-FDI.

\section{Summary and concluding remarks}

In this paper, we examine how foreign acquisition influences the capacity to generate innovations within firms in the host economy. We study this question within the context of the acquisition of an $\mathrm{R} \& \mathrm{D}$ active domestic firm by a foreign multinational. We provide evidence that acquisition FDI from technologically advanced countries increases the probability of closing research facilities. Conditional on keeping the newly acquired $R \& D$ lab, these same MNEs reorganize their research inputs to become more skill intensive and there are transfers of technology from the MNE. Alongside these changes to R\&D expenditures the subsidiary's innovativeness increases. For acquisitions by non-frontier MNEs we find fewer significant changes to $R \& D$ post-acquisition and no increases in patents. We propose that the complementarity between technology transfers and high-skilled workers is a plausible explanation for why there is a simultaneous rise in high-skilled workers, technology transfers, innovation and productivity of high-skilled workers after acquisition. Our evidence suggests that knowledge assets of the target firm may be a motive for acquisition FDI. Together our findings support the role of ownership to transfer intangibles within the MNE.

The aggregate effect of FDI on domestic technology production is significant and positive, accounting for $7.14 \%$ of the Spanish technology index, where this is mostly due to the technology transfers received from MNEs at the technological frontier. We incorporate the possibility of R\&D spillovers within the analysis, but find no significant changes of this type for non-acquired firms. 


\section{REFERENCES}

Acemoglu, D. (2007): “Equilibrium Bias of Technology” Econometrica 75(5), 1371-1409.

Acemoglu, D. (2009): Introduction to Modern Economic Growth, Princeton: Princeton University Press.

Aghion, P, Akcigit, U. and P. Howitt (2014): "What do we learn from Schumpeterian growth theory?" P. Aghion, S.N. Durlauf (Eds.), Handbook of Economic Growth (1st ed.), Elsevier, Vol. 2:515563

Arkolakis, C., N. Ramondo, A. Rodríguez-Clare, and S. Yeaple (2013): "Innovation and Production in the Global Economy” NBER Working Paper No. 18972.

Arnold, J. and B. Javorcik (2009): "Gifted Kids or Pushy Parents? Foreign Direct Investment and Plant Productivity in Indonesia" Journal of International Economics 79 (1): $42-53$

Atalay, E., Hortaçsu A. and C. Syverson (2014): "Vertical Integration and Input Flows" American Economic Review 104(4): 1120-1148(29).

Balsvik, R. (2011): “Is Labor Mobility a Channel for Spillovers from Multinationals? Evidence from Norwegian Manufacturing" The Review of Economics and Statistics 93(1): 285-297.

Balsvik, R. and S. Haller (2010): "Picking "Lemons" or Picking "Cherries"? Domestic and Foreign Acquisitions in Norwegian Manufacturing”Scandinavian Journal of Economics 112: 361-387.

Bandick, R., Görg, H., and P. Karpaty (2014): "Foreign Acquisitions, Domestic Multinationals, and R\&D” The Scandinavian Journal of Economics 116(4): 1091-1115.

Bertrand, O. (2009): "Effects of Foreign Acquisitions on R\&D Activity: Evidence from Firm-level Data for France" Research Policy 38(6): 1021-1031.

Bertrand, O., and P. Zuniga (2006): "R\&D and M\&A: Are cross-border M\&A different? An investigation on OECD countries" International Journal of Industrial Organization 24 (2): 401-423.

Bertrand, O. Hakkala, K., Norbäck, P.J., and Persson, L. (2012): "Should Countries Block Foreign Takeovers of R\&D Champions and Promote Greenfield Entry?" Canadian Journal of Economics 45(3): 1083-1124.

Bilir, L. K. and E. Morales (2016): "The Impact of Innovation in the Multinational Firm", NBER Working Paper No. 22160

Bloom, N., M. Schankerman, and J. Van Reenen (2016): Identifying Technology Spillovers and Product Market Rivalry” Econometrica 81(4): 1347-1393. 
Bloom, N., Draca, M. and J. Van Reenen (2015): "Trade Induced Technical Change? The Impact of Chinese Imports on Innovation, IT and Productivity" Review of Economic Studies 83 (1): 87117.

Bloom, N., Sadun, R., and J. Van Reenen (2012): “The Organization of Firms Across Countries" The Quarterly Journal of Economics 127 (4): 1663-1705.

Bloom, N., and R. Griffith R (2001): “The Internationalisation of R\&D” Fiscal Studies 22 (3): 337 355.

Branstetter, L. Fisman, R., and C. F. Foley (2006): "Do Stronger Intellectual Property Rights Increase International Technology Transfer? Empirical Evidence from U. S. Firm-Level Panel Data" The Quarterly Journal of Economics 121: 321-349.

Braguinsky, S., Ohyama, A., Okazaki, T., and C. Syverson (2015): “Acquisitions, Productivity, and Profitability: Evidence from the Japanese Cotton Spinning Industry" American Economic Review 105(7): 2086-2119.

Chen, W. (2011): “The Effect of Investor Origin on Firm Performance: Domestic and Foreign Direct Investment in the United States" Journal of International Economics 83: 219-228.

Coe, D., and Helpman, E. (1995): “International R\&D Spillovers" European Economic Review 39: 859-887.

Criscuolo, C. and R. Martin (2009): "Multinationals and U.S. Productivity Leadership: Evidence from Great Britain” The Review of Economics and Statistics 91(2): 263-281.

Criscuolo, C., Haskel, J., and M. Slaughter (2010): “Global Engagement and the Innovation Activities of Firms" International Journal of Industrial Organization 28: 191-202.

Denicolò, V. and M. Polo (2018a): “The Innovation Theory of Harm: An Appraisal” Bocconi University IEFE Working Paper No. 103

Denicolò, V. and M. Polo (2018b): “Duplicative research, mergers and innovation” Economic Letters 166: 56-59.

DIW (2016): Medium-sized Foreign-owned German Enterprises Heavily Involved in R\&D, DIW Economic Bulletin 22+23.2016

Dunning, J. and S. Lundan (2008): Multinational Enterprises and the Global Economy, Cheltenham, UK, Edward Elgar Publishing.

Ekholm, K. and K. Hakkala (2007): "Location of R\&D and High-tech Production by Vertically Integrated Multinationals" The Economic Journal 117(March): 512-543.

European Commission (2010): European Innovation Scoreboard (EIS) 2009, European Commission Enterprise and Industry. 
Federico G., G. Langus and T. Valletti (2017): “A Simple Model of Mergers and Innovation," Economics Letters 157: 136-140.

Girma, S., Kneller, R., and M. Pisu (2007): "Do Exporters Have Anything to Learn from Foreign Multinationals?" European Economic Review 51: 993-1010.

Girma, S., Gong, Y., Görg, H. and S. Lancheros (2015): "Estimating Direct and Indirect Effects of Foreign Direct Investment on Firm Productivity in the Presence of Interactions between Firms". Journal of International Economics 95(1): 157-169.

Greenaway, D., and R. Kneller (2007): "Firm Heterogeneity, Exporting and Foreign Direct Investment" Economic Journal 117: F134-F161.

Griliches, Z. (1992): “The Search for R\&D spillovers” Scandinavian Journal of Economics 94: 29-47. Guadalupe, M., Kuzmina, O., and C. Thomas (2012): “Innovation and Foreign Ownership” American Economic Review 102(7): 3594-3627.

Harris, R., and C. Robinson (2002): "The Effect of Foreign Acquisitions on Total Factor Productivity: Plant-Level Evidence from U.K. Manufacturing, 1987-1992” The Review of Economics and Statistics 84: 562-568.

Haucap, J., A. Rasch, and J. Stiebale (2018): "How Mergers Affect Innovation: Theory and Evidence” International Journal of Industrial Organization In Press, Accepted Manuscript.

Helpman, E. (1984): “A Simple Theory of International Trade with Multinational Corporations" Journal of Political Economy 92(3): 451-471.

Jaffe, A. B., M. Trajtenberg, and R. Henderson, (1993): “Geographical Localization of Knowledge Spillovers as Evidenced by Patent Citations" Quarterly Journal of Economics 108: 577-98.

Javorcik. B. and S. Poelhekke (2017): "Former Foreign Affiliates: Cast Out and Outperformed" Journal of the European Economic Association 15(3): 1-35.

Jullien, B. and Y. Lefouili (2018): "Horizontal Mergers and Innovation" Toulouse School of Economics Working Paper No. 18-892.

Keller, W. (2004): “International Technology Diffusion” Journal of Economic Literature 42: 752-782. Keller, W. (2010): "International Trade, Foreign Direct Investment, and Technology Spillovers" Handbook of the Economics of Innovation, Amsterdam, Elsevier North-Holland.

Keller, W. and S. Yeaple (2013): "The Gravity of Knowledge" American Economic Review 103(4): 1414-1444.

Leuven, E., and B. Sianesi (2003): "PSMATCH2: Stata Module to Perform Full Mahalanobis and Propensity Score Matching, Common Support Graphing, and Covariate Imbalance Testing, Statistical Software Components”, Boston College Department of Economics. 
Lopez A., and X. Vives (forthcoming): “Overlapping Ownership, R\&D Spillovers, and Antitrust Policy” Journal of Political Economy.

Maksimovic, V., Phillips, G., and N. Prabhala (2011): "Post-merger Restructuring and the Boundaries of Firms" Journal of Financial Economics 102(2): 317-343.

Markusen, J. (1984): “Multinationals, Multi-Plant Economies, and the Gains from Trade” Journal of International Economics 16 (3-4): 205-26.

Melitz, M. (2003): “The Impact of Trade on Intra-Industry Reallocations And Aggregate Industry Productivity" Econometrica v71(6): 1695-1725.

Moraga-González, J., Motchenkova, E., and S. Nevrekar (2018): "Merger and Innovation Portfolios" Mimeo.

National Science Foundation (NSF) (2016): "R\&D Performance of U.S.-Located Multinational Companies: Results from Multiagency Survey Linking Project” InfoBrief NCSES 16-305.

Nocke, V., and S. Yeaple (2008): “An Assignment Theory of Foreign Direct Investment” Review of Economic Studies 75: 529-557.

Rosenbaum, P., and D. Rubin (1985): “Constructing a Control Group Using Multivariate Matched Sampling Methods that Incorporate the Propensity Score” American Statistician 39: 33-38.

Stiebale, J. and F. Reize (2011): “The Impact of FDI through Mergers and Acquisitions on Innovation in Target Firms" International Journal of Industrial Organization 29: 155-167.

Stiebale, J. (2016): “Cross-border M\&As and Innovative Activity of Acquiring and Target Firms," Journal of International Economics 99: 1-15.

Szücs, F. (2014): “M\&A and R\&D: Asymmetric effects on acquirers and targets?” Research Policy 43 (7): 1264-1273.

UNCTAD (2005): "World Investment Report 2005: Transnational Corporations and the Internationalization of R\&D”, United Nations.

UNCTAD (2007): “World Investment Report 2007: Transnational corporations, extractive industries and development", United Nations.

Veugelers, R., and B. Cassiman (2004): "Foreign Subsidiaries as a Channel of International Technology Diffusion: Some direct firm level evidence from Belgium” European Economic Review 48: 455-476. 


\section{TABLES AND FIGURES}

Table 1: Summary Statistics of Innovation Expenditures by Type of Firm

\begin{tabular}{|c|c|c|c|c|c|c|c|c|c|c|}
\hline \multirow[b]{2}{*}{ Year } & \multicolumn{3}{|c|}{ All foreign acquired firms } & \multicolumn{3}{|c|}{ Frontier foreign acquired } & \multicolumn{3}{|c|}{$\begin{array}{c}\begin{array}{c}\text { Non-frontier foreign } \\
\text { acquired }\end{array} \\
\end{array}$} & \multirow[t]{2}{*}{$\begin{array}{c}\text { Non } \\
\text { acquired }\end{array}$} \\
\hline & $t-1$ & $t$ & $t+1$ & $t-1$ & $t$ & $t+1$ & $t-1$ & $t$ & $t+1$ & \\
\hline Total Innovation Expenditure (log) & $\begin{array}{l}11.35 \\
(4.77)\end{array}$ & $\begin{array}{l}10.41 \\
(5.52)\end{array}$ & $\begin{array}{l}10.31 \\
(5.61)\end{array}$ & $\begin{array}{l}11.27 \\
(4.56)\end{array}$ & $\begin{array}{c}9.88 \\
(5.80)\end{array}$ & $\begin{array}{l}10.09 \\
(5.69)\end{array}$ & $\begin{array}{l}11.41 \\
(4.88)\end{array}$ & $\begin{array}{l}10.72 \\
(5.34)\end{array}$ & $\begin{array}{l}10.33 \\
(5.65)\end{array}$ & $\begin{array}{c}9.82 \\
(4.97)\end{array}$ \\
\hline \multicolumn{11}{|l|}{ share of total innovation expenditure on... } \\
\hline Internal R\&D & $\begin{array}{c}0.78 \\
(0.30)\end{array}$ & $\begin{array}{c}0.71 \\
(0.34)\end{array}$ & $\begin{array}{c}0.73 \\
(0.34)\end{array}$ & $\begin{array}{c}0.82 \\
(0.29)\end{array}$ & $\begin{array}{c}0.70 \\
(0.35)\end{array}$ & $\begin{array}{c}0.67 \\
(0.37)\end{array}$ & $\begin{array}{c}0.75 \\
(0.30)\end{array}$ & $\begin{array}{c}0.72 \\
(0.33)\end{array}$ & $\begin{array}{c}0.76 \\
(0.33)\end{array}$ & $\begin{array}{c}0.72 \\
(0.33)\end{array}$ \\
\hline External R\&D & $\begin{array}{l}0.08 \\
(0.17)\end{array}$ & $\begin{array}{c}0.12 \\
(0.23)\end{array}$ & $\begin{array}{c}0.10 \\
(0.22)\end{array}$ & $\begin{array}{c}0.06 \\
(0.17)\end{array}$ & $\begin{array}{c}0.13 \\
(0.26)\end{array}$ & $\begin{array}{c}0.12 \\
(0.26)\end{array}$ & $\begin{array}{c}0.09 \\
(0.17)\end{array}$ & $\begin{array}{c}0.12 \\
(0.22)\end{array}$ & $\begin{array}{c}0.10 \\
(0.20)\end{array}$ & $\begin{array}{c}0.11 \\
(0.21)\end{array}$ \\
\hline Non-R\&D innovation & $\begin{array}{c}0.16 \\
(0.28)\end{array}$ & $\begin{array}{c}0.17 \\
(0.29)\end{array}$ & $\begin{array}{c}0.17 \\
(0.30)\end{array}$ & $\begin{array}{c}0.14 \\
(0.26)\end{array}$ & $\begin{array}{c}0.18 \\
(0.28)\end{array}$ & $\begin{array}{c}0.20 \\
(0.32)\end{array}$ & $\begin{array}{c}0.18 \\
(0.29)\end{array}$ & $\begin{array}{c}0.16 \\
(0.29)\end{array}$ & $\begin{array}{c}0.14 \\
(0.29)\end{array}$ & $\begin{array}{c}0.18 \\
(0.30)\end{array}$ \\
\hline Total External R\&D Expenditure (log) & $\begin{array}{l}3.66 \\
(5.55)\end{array}$ & $\begin{array}{c}3.94 \\
(5.71)\end{array}$ & $\begin{array}{l}3.47 \\
(5.53)\end{array}$ & $\begin{array}{c}2.62 \\
(5.04)\end{array}$ & $\begin{array}{c}3.83 \\
(5.74)\end{array}$ & $\begin{array}{c}3.67 \\
(5.68)\end{array}$ & $\begin{array}{c}4.22 \\
(5.78)\end{array}$ & $\begin{array}{c}3.96 \\
(5.70)\end{array}$ & $\begin{array}{c}3.35 \\
(5.46)\end{array}$ & $\begin{array}{c}3.47 \\
(5.18)\end{array}$ \\
\hline \multicolumn{11}{|l|}{ share of external R\&D on... } \\
\hline External domestic & $\begin{array}{c}0.73 \\
(0.40)\end{array}$ & $\begin{array}{c}0.69 \\
(0.41)\end{array}$ & $\begin{array}{c}0.78 \\
(0.38)\end{array}$ & $\begin{array}{c}0.66 \\
(0.43)\end{array}$ & $\begin{array}{c}0.64 \\
(0.43)\end{array}$ & $\begin{array}{c}0.69 \\
(0.43)\end{array}$ & $\begin{array}{c}0.73 \\
(0.41)\end{array}$ & $\begin{array}{c}0.70 \\
(0.42)\end{array}$ & $\begin{array}{c}0.80 \\
(0.36)\end{array}$ & $\begin{array}{c}0.94 \\
(0.20)\end{array}$ \\
\hline External foreign & $\begin{array}{c}0.27 \\
(0.40)\end{array}$ & $\begin{array}{c}0.31 \\
(0.41)\end{array}$ & $\begin{array}{c}0.22 \\
(0.38)\end{array}$ & $\begin{array}{c}0.34 \\
(0.43)\end{array}$ & $\begin{array}{c}0.36 \\
(0.43)\end{array}$ & $\begin{array}{c}0.31 \\
(0.43)\end{array}$ & $\begin{array}{c}0.27 \\
(0.41)\end{array}$ & $\begin{array}{c}0.30 \\
(0.42)\end{array}$ & $\begin{array}{c}0.20 \\
(0.36)\end{array}$ & $\begin{array}{c}0.06 \\
(0.20)\end{array}$ \\
\hline Total External Foreign Expenditure (log) & $\begin{array}{c}1.41 \\
(3.94)\end{array}$ & $\begin{array}{c}1.66 \\
(4.19)\end{array}$ & $\begin{array}{c}1.17 \\
(3.52)\end{array}$ & $\begin{array}{c}1.19 \\
(3.69)\end{array}$ & $\begin{array}{c}1.79 \\
(4.45)\end{array}$ & $\begin{array}{c}1.60 \\
(4.10)\end{array}$ & $\begin{array}{c}1.63 \\
(4.20)\end{array}$ & $\begin{array}{c}1.65 \\
(4.13)\end{array}$ & $\begin{array}{l}1.08 \\
(3.36)\end{array}$ & $\begin{array}{l}0.43 \\
(2.15)\end{array}$ \\
\hline share of external foreign $R \& D$ on... & & & & & & & & & & \\
\hline $\begin{array}{l}\text { External-Foreign - same business group } \\
\text { (Technology transfers) }\end{array}$ & $\begin{array}{c}0.60 \\
(0.48)\end{array}$ & $\begin{array}{c}0.65 \\
(0.46)\end{array}$ & $\begin{array}{c}0.61 \\
(0.48)\end{array}$ & $\begin{array}{c}0.55 \\
(0.50)\end{array}$ & $\begin{array}{c}0.74 \\
(0.40)\end{array}$ & $\begin{array}{c}0.79 \\
(0.40)\end{array}$ & $\begin{array}{c}0.62 \\
(0.48)\end{array}$ & $\begin{array}{c}0.62 \\
(0.49)\end{array}$ & $\begin{array}{c}0.48 \\
(0.50)\end{array}$ & $\begin{array}{c}0.05 \\
(0.21)\end{array}$ \\
\hline External-Foreign - other private firms & $\begin{array}{c}0.34 \\
(0.47)\end{array}$ & $\begin{array}{l}0.30 \\
(0.44)\end{array}$ & $\begin{array}{c}0.21 \\
(0.39)\end{array}$ & $\begin{array}{l}0.35 \\
(0.47)\end{array}$ & $\begin{array}{c}0.26 \\
(0.40)\end{array}$ & $\begin{array}{c}0.21 \\
(0.40)\end{array}$ & $\begin{array}{c}0.34 \\
(0.47)\end{array}$ & $\begin{array}{c}0.31 \\
(0.45)\end{array}$ & $\begin{array}{c}0.21 \\
(0.41)\end{array}$ & $\begin{array}{c}0.75 \\
(0.42)\end{array}$ \\
\hline External-Foreign - non-private firms & $\begin{array}{c}0.06 \\
(0.24)\end{array}$ & $\begin{array}{c}0.04 \\
(0.20)\end{array}$ & $\begin{array}{c}0.18 \\
(0.39)\end{array}$ & $\begin{array}{c}0.10 \\
(0.32)\end{array}$ & $\begin{array}{c}0.00 \\
(0.00)\end{array}$ & $\begin{array}{c}0.00 \\
(0.00)\end{array}$ & $\begin{array}{c}0.04 \\
(0.20)\end{array}$ & $\begin{array}{c}0.07 \\
(0.25)\end{array}$ & $\begin{array}{c}0.31 \\
(0.48) \\
\end{array}$ & $\begin{array}{c}0.20 \\
(0.38)\end{array}$ \\
\hline Number of firms & 300 & 300 & 228 & 104 & 104 & 71 & 196 & 196 & 157 & 7,419 \\
\hline
\end{tabular}

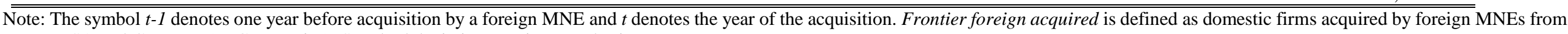
Japan, USA and Germany (JUG countries). Standard deviations are in parenthesis. 
Table 2: Determinants of Acquisition: Probability of being acquired

\begin{tabular}{|c|c|c|c|c|c|c|c|}
\hline $\begin{array}{l}\text { Sample } \\
\text { Regression No. }\end{array}$ & $\begin{array}{l}\text { All firms } \\
\text { (i) }\end{array}$ & $\begin{array}{l}\text { All firms } \\
\text { (ii) }\end{array}$ & $\begin{array}{l}\text { All firms } \\
\text { (iii) }\end{array}$ & $\begin{array}{l}\text { All firms } \\
\text { (iv) }\end{array}$ & $\begin{array}{c}\text { Frontier vs. } \\
\text { non-acquired } \\
\text { (v) }\end{array}$ & $\begin{array}{l}\text { Non-frontier vs. non- } \\
\text { acquired } \\
\text { (vi) }\end{array}$ & $\begin{array}{l}\text { Frontier vs. } \\
\text { non-frontier } \\
\text { (vii) }\end{array}$ \\
\hline Log(Total innovation expenditure) & $\begin{array}{l}0.0001 \\
(0.000)\end{array}$ & $\begin{array}{l}0.0003 \\
(0.000)\end{array}$ & & & & & \\
\hline Log(Total innovation /turnover) & $\begin{array}{c}-0.0004 \\
(0.003)\end{array}$ & $\begin{array}{r}-0.0009 \\
(0.004)\end{array}$ & & & & & \\
\hline External $R \& D /$ internal $R \& D$ & & $\begin{array}{l}-0.0000 \\
(0.000)\end{array}$ & & & & & \\
\hline $\log ($ internal $R \& D)$ & & & $\begin{array}{l}0.0002 * * * \\
(0.000)\end{array}$ & $\begin{array}{l}0.0002 * * * \\
(0.000)\end{array}$ & $\begin{array}{c}0.0001 * \\
(0.000)\end{array}$ & $\begin{array}{c}0.0001 * * \\
(0.000)\end{array}$ & $\begin{array}{l}0.0000 \\
(0.000)\end{array}$ \\
\hline $\log ($ external $R \& D)$ & & & $\begin{array}{c}-0.0003 * * * \\
(0.000)\end{array}$ & $\begin{array}{c}-0.0003^{* * *} \\
(0.000)\end{array}$ & $\begin{array}{c}-0.0002 * * * \\
(0.000)\end{array}$ & $\begin{array}{c}-0.0001 * * \\
(0.000)\end{array}$ & $\begin{array}{l}-0.0000 \\
(0.000)\end{array}$ \\
\hline $\begin{array}{l}\text { External } R \& D \text { same } \\
\text { business group/external } R \& D\end{array}$ & & $\begin{array}{l}0.0000 \\
(0.000)\end{array}$ & $\begin{array}{l}0.0000 \\
(0.000)\end{array}$ & & & & \\
\hline $\begin{array}{l}\text { External } R \& D \text { same } \\
\text { business group dummy }\end{array}$ & & $\begin{array}{c}0.0424 * * \\
(0.017)\end{array}$ & $\begin{array}{l}0.0633 * * * \\
(0.020)\end{array}$ & $\begin{array}{l}0.0736 * * * \\
(0.016)\end{array}$ & $\begin{array}{c}0.0364 * * \\
(0.014)\end{array}$ & $\begin{array}{l}0.0562 * * * \\
(0.016)\end{array}$ & $\begin{array}{l}0.0000 \\
(0.000)\end{array}$ \\
\hline Labour productivity & $\begin{array}{l}0.0028 * * * \\
(0.000)\end{array}$ & $\begin{array}{l}0.0036 * * * \\
(0.001)\end{array}$ & $\begin{array}{l}0.0026 * * * \\
(0.000)\end{array}$ & $\begin{array}{l}0.0026 * * * \\
(0.000)\end{array}$ & $\begin{array}{l}0.0011 * * * \\
(0.000)\end{array}$ & $\begin{array}{l}0.0015^{* * * *} \\
(0.000)\end{array}$ & $\begin{array}{l}-0.0000 \\
(0.000)\end{array}$ \\
\hline $\begin{array}{l}\text { Physical investment } \\
\text { per employee }\end{array}$ & $\begin{array}{r}-0.0001 \\
(0.000)\end{array}$ & $\begin{array}{c}-0.0003^{* *} \\
(0.000)\end{array}$ & $\begin{array}{r}-0.0001 \\
(0.000)\end{array}$ & $\begin{array}{r}-0.0001 \\
(0.000)\end{array}$ & $\begin{array}{l}0.0001 \\
(0.000)\end{array}$ & $\begin{array}{r}-0.0001 \\
(0.000)\end{array}$ & $\begin{array}{l}0.0000 \\
(0.000)\end{array}$ \\
\hline Sales growth & $\begin{array}{c}-0.0022 * * * \\
(0.001)\end{array}$ & $\begin{array}{l}-0.0025 * * \\
(0.001)\end{array}$ & $\begin{array}{c}-0.0021 * * * \\
(0.001)\end{array}$ & $\begin{array}{c}-0.0021 * * * \\
(0.001)\end{array}$ & $\begin{array}{c}-0.0011 * * \\
(0.001)\end{array}$ & $\begin{array}{c}-0.0013^{* *} \\
(0.000)\end{array}$ & $\begin{array}{l}-0.0000 \\
(0.000)\end{array}$ \\
\hline Size $<50$ employees & $\begin{array}{l}-0.0133 * * * \\
(0.002)\end{array}$ & $\begin{array}{c}-0.0121 * * * \\
(0.002)\end{array}$ & $\begin{array}{l}-0.0115 * * * \\
(0.002)\end{array}$ & $\begin{array}{c}-0.0114 * * * \\
(0.002)\end{array}$ & $\begin{array}{c}-0.0041 * * * \\
(0.001)\end{array}$ & $\begin{array}{l}-0.0083 * * * \\
(0.001)\end{array}$ & $\begin{array}{l}0.0000 \\
(0.000)\end{array}$ \\
\hline Size: 50-99 employees & $\begin{array}{c}-0.0039 * * * \\
(0.001)\end{array}$ & $\begin{array}{c}-0.0041^{* * * *} \\
(0.001)\end{array}$ & $\begin{array}{c}-0.0035^{* * * *} \\
(0.001)\end{array}$ & $\begin{array}{c}-0.0035^{* * * *} \\
(0.001)\end{array}$ & $\begin{array}{c}-0.0009 * * \\
(0.000)\end{array}$ & $\begin{array}{c}-0.0028 * * * \\
(0.000)\end{array}$ & $\begin{array}{l}0.0000 \\
(0.000)\end{array}$ \\
\hline Size: 200-499 employees & $\begin{array}{r}-0.0001 \\
(0.001)\end{array}$ & $\begin{array}{c}-0.0008 \\
(0.001)\end{array}$ & $\begin{array}{r}-0.0003 \\
(0.001)\end{array}$ & $\begin{array}{r}-0.0003 \\
(0.001)\end{array}$ & $\begin{array}{l}0.0004 \\
(0.001)\end{array}$ & $\begin{array}{c}-0.0009 \\
(0.001)\end{array}$ & $\begin{array}{l}0.0000 \\
(0.000)\end{array}$ \\
\hline Size: $>=500$ employees & $\begin{array}{l}0.0013 \\
(0.002)\end{array}$ & $\begin{array}{l}0.0000 \\
(0.002)\end{array}$ & $\begin{array}{l}0.0007 \\
(0.001)\end{array}$ & $\begin{array}{c}0.0008 \\
(0.001)\end{array}$ & $\begin{array}{r}-0.0001 \\
(0.001)\end{array}$ & $\begin{array}{l}0.0005 \\
(0.001)\end{array}$ & $\begin{array}{c}-0.0000 \\
(0.000)\end{array}$ \\
\hline Observations & 24,157 & 17,249 & 24,157 & 24,157 & 21,180 & 23,916 & 1,476 \\
\hline
\end{tabular}

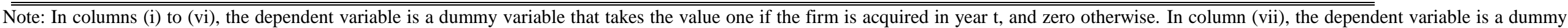

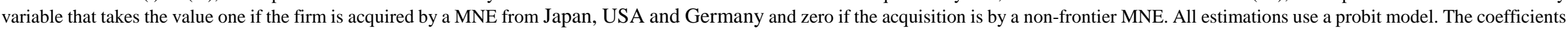

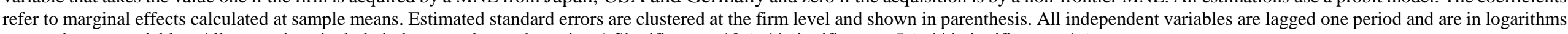
except dummy variables. All regressions include industry and year dummies. * Significant at $10 \%$.* significant at $5 \%$. *** significant at $1 \%$ 
Table 3: Test of balancing hypothesis

Table B3a: Test of balancing hypothesis for non-quitters and quitters

\begin{tabular}{|c|c|c|c|c|c|c|c|c|}
\hline \multirow[t]{2}{*}{ Sample of firms: } & \multicolumn{4}{|c|}{$\begin{array}{c}\text { Test of balancing hypothesis for } \\
\text { non-quitters and quitters }\end{array}$} & \multicolumn{4}{|c|}{$\begin{array}{l}\text { Test of balancing hypothesis for } \mathrm{R} \& \mathrm{D} \\
\text { active firms }\end{array}$} \\
\hline & Treated & Control & t-test & p-value & Treated & Control & t-test & p-value \\
\hline Log(internal $R \& D)$ & 10.44 & 10.66 & -0.46 & 0.64 & 12.56 & 11.98 & 1.52 & 0.13 \\
\hline $\log ($ external $R \& D)$ & 3.41 & 3.21 & 0.38 & 0.70 & 4.12 & 3.99 & 0.18 & 0.85 \\
\hline External same business group dummy & 0.04 & 0.04 & 0.25 & 0.81 & 0.05 & 0.05 & 0.04 & 0.97 \\
\hline Labour productivity & 12.16 & 12.10 & 0.66 & 0.51 & 12.27 & 12.12 & 1.39 & 0.17 \\
\hline Physical investment per employee & 6.95 & 7.48 & -1.70 & 0.09 & 7.41 & 7.91 & -1.47 & 0.14 \\
\hline Sales growth & 0.03 & 0.04 & -0.48 & 0.63 & 0.09 & 0.06 & 0.56 & 0.58 \\
\hline Size $<50$ employees & 0.25 & 0.24 & 0.23 & 0.82 & 0.20 & 0.21 & -0.17 & 0.87 \\
\hline Size: 50-99 employees & 0.17 & 0.13 & 1.10 & 0.27 & 0.18 & 0.12 & 1.46 & 0.15 \\
\hline Size: 200-499 employees & 0.19 & 0.18 & 0.13 & 0.90 & 0.19 & 0.19 & -0.06 & 0.95 \\
\hline Size: > =500 employees & 0.14 & 0.14 & 0.14 & 0.89 & 0.14 & 0.15 & -0.24 & 0.81 \\
\hline
\end{tabular}


Table 4: The Effect of Foreign Acquisition on the Probability of Stopping R\&D using a matched sample

\begin{tabular}{lcc}
\hline \hline Regression No. & (i) & $($ ii) \\
\hline Panel A: Probability of stopping R\&D during the sample period \\
Foreign acquired & $0.122^{* *}$ & \\
& $(0.052)$ & $0.168 * * *$ \\
Frontier foreign acquired & $(0.041)$ \\
& & $0.137 * *$ \\
Non-frontier foreign acquired & 2,300 & $(0.062)$ \\
& 2,300 \\
Observations & $0.416^{* * *}$ & \\
Panel B: Probability of stopping R\&D in a given year (hazard rate) \\
Foreign acquired & $(0.126)$ & $0.639 * * *$ \\
& & $(0.180)$ \\
Frontier foreign acquired & & 0.284 \\
& & $(0.188)$ \\
Non-frontier foreign acquired & 2,231 & 2,231 \\
\hline Observations & & \\
\hline \hline
\end{tabular}

Note: Frontier foreign acquired is defined as domestic firms acquired by Japan, Germany and USA. The dependent variable refers to whether a firm with positive internal $R \& D$ then become zero and remains so during the sample period. Panel A reports probit estimates on the probability of quitting R\&D during the sample period. We report marginal effects. Estimated standard errors are clustered at the industry level and shown in parenthesis. All regressions include sector trends and year dummies. Panel B reports Cox Proportional Hazard estimates. * Significant at 10\%;** Significant at 5\%; *** significant at $1 \%$.

Table 5: The Effect of Foreign Acquisition on Innovation Expenditures using a matched sample

\begin{tabular}{|c|c|c|c|c|c|c|}
\hline \multirow[b]{2}{*}{ Regression No. } & \multicolumn{6}{|c|}{ Dependent variable: Innovation Expenditures } \\
\hline & Total & $\begin{array}{c}\text { Internal } \\
\text { R\&D } \\
\text { Share } \\
\text { (ii) } \\
\end{array}$ & $\begin{array}{l}\text { External } \\
\text { R\&D } \\
\text { Share } \\
\text { (iii) } \\
\end{array}$ & $\begin{array}{c}\text { External } \\
\text { Domestic } \\
\text { Share } \\
\text { (iv) }\end{array}$ & $\begin{array}{c}\text { External } \\
\text { Foreign } \\
\text { Share } \\
(v) \\
\end{array}$ & $\begin{array}{c}\text { Technology } \\
\text { Transfer } \\
\text { Share } \\
\text { (vi) }\end{array}$ \\
\hline \multicolumn{7}{|c|}{ Frontier foreign acquired } \\
\hline Year of acquisition & $\begin{array}{c}0.148 * * \\
(0.059)\end{array}$ & $\begin{array}{c}-0.070 * * \\
(0.030)\end{array}$ & $\begin{array}{c}0.005 \\
(0.022)\end{array}$ & $\begin{array}{c}0.048 \\
(0.063)\end{array}$ & $\begin{array}{l}-0.052^{*} \\
(0.024)\end{array}$ & $\begin{array}{l}0.077 * \\
(0.037)\end{array}$ \\
\hline One year after & $\begin{array}{c}0.144 \\
(0.148)\end{array}$ & $\begin{array}{c}-0.083 * * \\
(0.036)\end{array}$ & $\begin{array}{l}-0.004 \\
(0.023)\end{array}$ & $\begin{array}{l}-0.010 \\
(0.070)\end{array}$ & $\begin{array}{c}-0.078 * \\
(0.037)\end{array}$ & $\begin{array}{c}0.035 \\
(0.046)\end{array}$ \\
\hline Two years after & $\begin{array}{c}0.944 * * \\
(0.331)\end{array}$ & $\begin{array}{c}-0.116 \\
(0.090)\end{array}$ & $\begin{array}{l}-0.002 \\
(0.017)\end{array}$ & $\begin{array}{l}0.227 * \\
(0.103)\end{array}$ & $\begin{array}{c}-0.067 * * \\
(0.026)\end{array}$ & $\begin{array}{c}0.078 \\
(0.046)\end{array}$ \\
\hline \multicolumn{7}{|c|}{ Non-frontier foreign acquired } \\
\hline Year of acquisition & $\begin{array}{c}-0.286^{*} \\
(0.148)\end{array}$ & $\begin{array}{l}-0.016 \\
(0.062)\end{array}$ & $\begin{array}{c}0.012 \\
(0.026)\end{array}$ & $\begin{array}{l}-0.017 \\
(0.052)\end{array}$ & $\begin{array}{l}-0.013 \\
(0.010)\end{array}$ & $\begin{array}{c}0.018 \\
(0.017)\end{array}$ \\
\hline One year after & $\begin{array}{c}-0.235 * * \\
(0.097)\end{array}$ & $\begin{array}{c}-0.014 \\
(0.040)\end{array}$ & $\begin{array}{l}-0.004 \\
(0.013)\end{array}$ & $\begin{array}{c}0.006 \\
(0.071)\end{array}$ & $\begin{array}{l}-0.005 \\
(0.010)\end{array}$ & $\begin{array}{c}0.001 \\
(0.014)\end{array}$ \\
\hline Two years after & $\begin{array}{l}-0.313 \\
(0.208)\end{array}$ & $\begin{array}{l}-0.040 \\
(0.050)\end{array}$ & $\begin{array}{c}0.000 \\
(0.036)\end{array}$ & $\begin{array}{c}-0.011 \\
(0.146)\end{array}$ & $\begin{array}{l}-0.042 \\
(0.037)\end{array}$ & $\begin{array}{c}0.006 \\
(0.042)\end{array}$ \\
\hline Observations & 981 & 981 & 981 & 981 & 981 & 981 \\
\hline$R$-squared & 0.232 & 0.190 & 0.183 & 0.173 & 0.112 & 0.171 \\
\hline
\end{tabular}

Note: Fixed effects-OLS estimates. Estimated standard errors are clustered at the industry level and shown in parenthesis. Frontier foreign acquired is defined as domestic firms acquired by Japan, Germany and USA. All regressions include firmfixed effects, sector trends and year dummies. Total $R \& D$ spending is the logged value. Internal and external $R \& D$ expenditures are sub-components of total innovation expenditures and are expressed as shares of this total. Internal R\&D is the R\&D undertaken within the firm; External R\&D is the purchases of R\&D by the firm; External domestic and external foreign are sub-components of external R\&D. External domestic is the R\&D acquired in Spain by the firm and external foreign are the imports of $\mathrm{R} \& \mathrm{D}$. Technology transfers is a sub-component of external foreign. Technology transfers are the imports of R\&D from the business group by the firm. * Significant at $10 \% ; * *$ Significant at 5\%; *** significant at $1 \%$. 


\begin{tabular}{|c|c|c|c|c|c|}
\hline \multirow[b]{2}{*}{ Regression No. } & \multicolumn{5}{|c|}{ Dependent variable: Employees by skill level } \\
\hline & $\begin{array}{c}\text { Total } \\
\text { (i) }\end{array}$ & $\begin{array}{c}\text { Ph.D. } \\
\text { (ii) }\end{array}$ & $\begin{array}{c}\text { 5-year } \\
\text { Undergrad } \\
\text { degree } \\
\text { (iii) }\end{array}$ & $\begin{array}{c}\text { 3-year } \\
\text { Undergrad } \\
\text { degree } \\
\text { (iv) }\end{array}$ & $\begin{array}{c}\text { Without } \\
\text { higher } \\
\text { education } \\
\text { (v) }\end{array}$ \\
\hline \multicolumn{6}{|c|}{ Frontier foreign acquired } \\
\hline Year of acquisition & $\begin{array}{c}0.115 \\
(0.183)\end{array}$ & $\begin{array}{c}0.075 * * * \\
(0.023)\end{array}$ & $\begin{array}{c}0.230 \\
(0.149)\end{array}$ & $\begin{array}{l}-0.055 \\
(0.078)\end{array}$ & $\begin{array}{c}0.081 \\
(0.115)\end{array}$ \\
\hline One year after & $\begin{array}{c}0.112 \\
(0.158)\end{array}$ & $\begin{array}{c}0.013 \\
(0.050)\end{array}$ & $\begin{array}{c}0.229 \\
(0.214)\end{array}$ & $\begin{array}{c}0.060 \\
(0.154)\end{array}$ & $\begin{array}{c}0.041 \\
(0.144)\end{array}$ \\
\hline Two years after & $\begin{array}{l}0.406 * \\
(0.211)\end{array}$ & $\begin{array}{c}0.224 \\
(0.184)\end{array}$ & $\begin{array}{c}0.241 \\
(0.311)\end{array}$ & $\begin{array}{c}0.498 \\
(0.307)\end{array}$ & $\begin{array}{c}0.672 \\
(0.437)\end{array}$ \\
\hline \multicolumn{6}{|c|}{ Non-frontier foreign acquired } \\
\hline Year of acquisition & $\begin{array}{c}-0.233^{* *} \\
(0.083)\end{array}$ & $\begin{array}{l}-0.099 \\
(0.112)\end{array}$ & $\begin{array}{c}-0.296 * * * \\
(0.066)\end{array}$ & $\begin{array}{c}0.013 \\
(0.049)\end{array}$ & $\begin{array}{l}-0.077 \\
(0.105)\end{array}$ \\
\hline One year after & $\begin{array}{c}-0.285^{* *} * \\
(0.093)\end{array}$ & $\begin{array}{c}0.077 \\
(0.062)\end{array}$ & $\begin{array}{c}-0.263^{* *} \\
(0.106)\end{array}$ & $\begin{array}{l}-0.146 \\
(0.109)\end{array}$ & $\begin{array}{l}-0.122 \\
(0.123)\end{array}$ \\
\hline Two years after & $\begin{array}{c}-0.272 * * \\
(0.111)\end{array}$ & $\begin{array}{l}-0.077 \\
(0.098)\end{array}$ & $\begin{array}{l}-0.168 \\
(0.161)\end{array}$ & $\begin{array}{l}-0.104 \\
(0.209)\end{array}$ & $\begin{array}{l}-0.086 \\
(0.177)\end{array}$ \\
\hline Observations & 981 & 981 & 981 & 981 & 981 \\
\hline$R$-squared & 0.296 & 0.187 & 0.297 & 0.162 & 0.224 \\
\hline
\end{tabular}

Note: Fixed effects-OLS estimates. Estimated standard errors are clustered at the industry level and shown in parenthesis.

Frontier foreign acquired is defined as domestic firms acquired by Japan, USA and Germany. Dependent variables are the logarithm of the number of employees. All regressions include firm-fixed effects, sector trends and year dummies. *

Significant at $10 \% ; * *$ Significant at $5 \% ; * * *$ significant at $1 \%$.

Table 7: The Effect of Foreign Acquisition on Innovation Output using a matched sample

\begin{tabular}{|c|c|c|c|c|c|c|}
\hline \multirow[b]{2}{*}{ Regression No. } & \multicolumn{6}{|c|}{ Dependent variable: Innovation output } \\
\hline & $\begin{array}{c}\text { Patents/ } \\
\text { internal } \\
\text { R\&D } \\
\text { (i) }\end{array}$ & $\begin{array}{c}\text { Product } \\
\text { innovation } \\
\text { (ii) }\end{array}$ & $\begin{array}{c}\text { Process } \\
\text { innovation } \\
\text { (iii) } \\
\end{array}$ & $\begin{array}{c}\text { Patents/ } \\
\text { internal } \\
\text { R\&D } \\
\text { (iv) }\end{array}$ & $\begin{array}{c}\text { Product } \\
\text { innovation } \\
(\mathbf{v}) \\
\end{array}$ & $\begin{array}{c}\text { Process } \\
\text { innovation } \\
\text { (vi) }\end{array}$ \\
\hline \multicolumn{7}{|c|}{ Frontier foreign acquired } \\
\hline Year of acquisition & $\begin{array}{c}0.001 \\
(0.001)\end{array}$ & $\begin{array}{c}0.039 \\
(0.038)\end{array}$ & $\begin{array}{l}-0.010 \\
(0.025)\end{array}$ & $\begin{array}{l}0.0009 \\
(0.001)\end{array}$ & $\begin{array}{c}0.039 \\
(0.038)\end{array}$ & $\begin{array}{l}-0.010 \\
(0.025)\end{array}$ \\
\hline One year after & $\begin{array}{c}0.002 * * \\
(0.001)\end{array}$ & $\begin{array}{c}0.040 \\
(0.031)\end{array}$ & $\begin{array}{c}0.029 * * \\
(0.011)\end{array}$ & $\begin{array}{c}0.0022 * * \\
(0.001)\end{array}$ & $\begin{array}{c}0.040 \\
(0.031)\end{array}$ & $\begin{array}{c}0.029 * * \\
(0.011)\end{array}$ \\
\hline Two years after & $\begin{array}{c}0.008 \\
(0.007)\end{array}$ & $\begin{array}{c}-0.136 \\
(0.213)\end{array}$ & $\begin{array}{c}0.081 * * \\
(0.026)\end{array}$ & $\begin{array}{l}0.0084 \\
(0.007)\end{array}$ & $\begin{array}{c}-0.136 \\
(0.213)\end{array}$ & $\begin{array}{c}0.080 * * \\
(0.026)\end{array}$ \\
\hline \multicolumn{7}{|c|}{ Non-frontier foreign acquired } \\
\hline Year of acquisition & $\begin{array}{c}-0.000 \\
(0.001)\end{array}$ & $\begin{array}{c}-0.020 \\
(0.052)\end{array}$ & $\begin{array}{c}0.022 \\
(0.028)\end{array}$ & $\begin{array}{l}-0.0002 \\
(0.000)\end{array}$ & $\begin{array}{c}-0.019 \\
(0.051)\end{array}$ & $\begin{array}{c}0.021 \\
(0.028)\end{array}$ \\
\hline One year after & $\begin{array}{l}-0.001 \\
(0.001)\end{array}$ & $\begin{array}{c}0.049 \\
(0.095)\end{array}$ & $\begin{array}{c}-0.051 \\
(0.082)\end{array}$ & $\begin{array}{c}-0.0004 \\
(0.001)\end{array}$ & $\begin{array}{c}0.044 \\
(0.099)\end{array}$ & $\begin{array}{c}-0.043 \\
(0.079)\end{array}$ \\
\hline Two years after & $\begin{array}{c}0.000 \\
(0.001)\end{array}$ & $\begin{array}{l}-0.006 \\
(0.102)\end{array}$ & $\begin{array}{c}0.028 \\
(0.190)\end{array}$ & $\begin{array}{l}0.0007 \\
(0.001)\end{array}$ & $\begin{array}{l}-0.010 \\
(0.105)\end{array}$ & $\begin{array}{c}0.033 \\
(0.190)\end{array}$ \\
\hline Lag exports & & & & $\begin{array}{c}0.0003 * \\
(0.000)\end{array}$ & $\begin{array}{c}-0.049 \\
(0.046)\end{array}$ & $\begin{array}{c}0.080 * * \\
(0.025)\end{array}$ \\
\hline Observations & 690 & 710 & 710 & 690 & 710 & 710 \\
\hline
\end{tabular}

Note: Fixed effects-OLS estimates. Estimated standard errors are clustered at the industry level and shown in parenthesis. Frontier foreign acquired is defined as domestic firms acquired by foreign MNEs from Japan, USA and Germany. The innovation output is the number of patents over internal $\mathrm{R} \& \mathrm{D}$, product and process innovation for the current year, one year and 2 years afterwards. Regressions include firm-fixed effects, sector trends and year dummies. * Significant at 10\%;** Significant at $5 \%$; *** significant at $1 \%$. 
Table 8: The Effect of Foreign Acquisition on the Domestic Innovation Index

\begin{tabular}{llcc|cc}
\hline \hline Innovation Measure: & \multicolumn{2}{c|}{ Patents } & \multicolumn{2}{c}{ Process Innovation } \\
\hline & & $\begin{array}{c}\text { Weights in terms of: } \\
\text { Internal R\&D } \\
\text { expenditures }\end{array}$ & $\begin{array}{c}\text { Total R\&D } \\
\text { expenditures } \\
\text { (i) }\end{array}$ & $\begin{array}{c}\text { Weights in terms of: } \\
\text { Internal R\&D } \\
\text { Total innovation } \\
\text { expenditures } \\
\text { (iii) }\end{array}$ & $\begin{array}{c}\text { expenditures } \\
\text { (iv) }\end{array}$ \\
\hline Within effect & Frontier & 2.59 & 2.72 & 0.23 & 0.30 \\
& Non-frontier & 0.00 & 0.00 & 0.00 & 0.00 \\
\hline Between effect & Frontier & 3.18 & 3.34 & 0.71 & 0.95 \\
& Non-frontier & -1.47 & -1.17 & -0.30 & -0.36 \\
\hline Cross effect & Frontier & 1.83 & 1.92 & 0.00 & 0.55 \\
& Non-frontier & 0.00 & 0.00 & 0.00 & -0.00 \\
\hline Exit & Frontier & -0.09 & -0.09 & -0.09 & -0.09 \\
& Non-frontier & -0.25 & -0.25 & -0.10 & 1.70 \\
\hline Total & Frontier & 7.68 & 8.06 & 0.86 & -0.56 \\
\hline Overall & Non-frontier & -1.23 & -0.92 & -0.40 & 1.15 \\
\hline \hline
\end{tabular}

Note: All figures are as a percentage of the total increase over the period 2004-2009.

Table 9: The Effect of Foreign Acquisition on Innovation Expenditures for R\&D active firms Using a Matched Sample: Alternative Definition of Technologically Intensive Foreign Acquisitions

\begin{tabular}{|c|c|c|c|c|c|c|}
\hline \multirow[b]{2}{*}{$\begin{array}{l}\text { Innovation } \\
\text { Expenditure } \\
\text { measure }\end{array}$} & \multicolumn{6}{|c|}{ Dependent variable: Innovation Measure } \\
\hline & $\begin{array}{c}\text { Hazard of } \\
\text { stopping } \\
\text { R\&D }\end{array}$ & Total R\&D & $\begin{array}{c}\text { Internal } \\
\text { R\&D } \\
\text { Share }\end{array}$ & $\begin{array}{c}\text { Technology } \\
\text { Transfer } \\
\text { Share }\end{array}$ & $\begin{array}{c}\text { Employees } \\
\text { with PhD }\end{array}$ & $\begin{array}{c}\text { Innovation } \\
\text { Output }\end{array}$ \\
\hline Regression No. & (i) & (ii) & (iii) & (iv) & (v) & (vi) \\
\hline $\begin{array}{l}\text { Frontier: above } 90^{\text {th }} \\
\text { percentile }\end{array}$ & $\begin{array}{c}1.190 * * * \\
(0.371)\end{array}$ & & & & & \\
\hline Year of acquisition & & $\begin{array}{c}0.018 \\
(0.255)\end{array}$ & $\begin{array}{l}-0.054 \\
(0.087)\end{array}$ & $\begin{array}{l}0.100 * \\
(0.049)\end{array}$ & $\begin{array}{l}0.232^{*} \\
(0.106)\end{array}$ & $\begin{array}{l}-0.001 \\
(0.001)\end{array}$ \\
\hline One year after & & $\begin{array}{c}0.329 * * * \\
(0.084)\end{array}$ & $\begin{array}{c}-0.160 * * \\
(0.068)\end{array}$ & $\begin{array}{c}0.067 \\
(0.057)\end{array}$ & $\begin{array}{c}0.111 \\
(0.091)\end{array}$ & $\begin{array}{l}0.003 * \\
(0.002)\end{array}$ \\
\hline Two years after & & $\begin{array}{l}0.624^{*} \\
(0.292)\end{array}$ & $\begin{array}{c}-0.288 * * * \\
(0.085)\end{array}$ & $\begin{array}{c}0.040 \\
(0.067)\end{array}$ & $\begin{array}{c}0.229 \\
(0.214)\end{array}$ & $\begin{array}{l}0.018 * \\
(0.009)\end{array}$ \\
\hline $\begin{array}{l}\text { Non-frontier: below- } \\
90^{\text {th }} \text { percentile }\end{array}$ & $\begin{array}{c}0.316 * * * \\
(0.118)\end{array}$ & & & & & \\
\hline Year of acquisition & & $\begin{array}{c}-0.129 \\
(0.101)\end{array}$ & $\begin{array}{l}-0.035 \\
(0.031)\end{array}$ & $\begin{array}{l}0.032 * \\
(0.017)\end{array}$ & $\begin{array}{l}-0.047 \\
(0.066)\end{array}$ & $\begin{array}{c}0.000 \\
(0.000)\end{array}$ \\
\hline One year after & & $\begin{array}{c}-0.150 * * \\
(0.061)\end{array}$ & $\begin{array}{l}-0.032 \\
(0.034)\end{array}$ & $\begin{array}{c}0.008 \\
(0.020)\end{array}$ & $\begin{array}{c}0.057 \\
(0.049)\end{array}$ & $\begin{array}{c}0.000 \\
(0.000)\end{array}$ \\
\hline Two years after & & $\begin{array}{l}-0.008 \\
(0.171)\end{array}$ & $\begin{array}{c}-0.038 \\
(0.050)\end{array}$ & $\begin{array}{c}0.025 \\
(0.023)\end{array}$ & $\begin{array}{l}-0.012 \\
(0.075)\end{array}$ & $\begin{array}{c}0.000 \\
(0.000)\end{array}$ \\
\hline Observations & 2,231 & 981 & 981 & 981 & 981 & 690 \\
\hline
\end{tabular}

Note: Frontier MNEs are defined as foreign acquisitions from countries with R\&D intensity at the $90^{\text {th }}$ percentile within a given industry. Fixed effects-OLS estimates. Estimated standard errors are clustered at the industry level and shown in parenthesis. * Significant at 10\%;** Significant at 5\%; *** significant at $1 \%$. 
Table 10: The Effect of Foreign Acquisition on Innovation Expenditures for a matched sample with matching procedure with two year pre-treatment effects

\begin{tabular}{|c|c|c|c|c|c|c|}
\hline \multirow[b]{2}{*}{$\begin{array}{l}\text { Innovation } \\
\text { Expenditure } \\
\text { measure }\end{array}$} & \multicolumn{6}{|c|}{ Dependent variable: Innovation Measure } \\
\hline & $\begin{array}{c}\text { Hazard of } \\
\text { stopping } \\
\text { R\&D }\end{array}$ & Total R\&D & $\begin{array}{c}\text { Internal } \\
\text { R\&D } \\
\text { Share }\end{array}$ & $\begin{array}{c}\text { Technology } \\
\text { Transfer } \\
\text { Share }\end{array}$ & $\begin{array}{l}\text { Employees } \\
\text { with PhD }\end{array}$ & $\begin{array}{c}\text { Innovation } \\
\text { Output }\end{array}$ \\
\hline Regression No. & (i) & (ii) & (iii) & (iv) & (v) & (vi) \\
\hline $\begin{array}{l}\text { Frontier foreign } \\
\text { acquired }\end{array}$ & $\begin{array}{c}0.655 * * * \\
(0.238)\end{array}$ & & & & & \\
\hline Year of acquisition & & $\begin{array}{c}0.070 \\
(0.081)\end{array}$ & $\begin{array}{c}-0.073 * * \\
(0.032)\end{array}$ & $\begin{array}{l}0.051 * \\
(0.023)\end{array}$ & $\begin{array}{c}0.056 * * \\
(0.019)\end{array}$ & $\begin{array}{c}0.001 \\
(0.001)\end{array}$ \\
\hline One year after & & $\begin{array}{c}0.133 \\
(0.158)\end{array}$ & $\begin{array}{l}-0.085^{*} \\
(0.043)\end{array}$ & $\begin{array}{c}0.017 \\
(0.035)\end{array}$ & $\begin{array}{c}0.024 \\
(0.016)\end{array}$ & $\begin{array}{l}0.002 * \\
(0.001)\end{array}$ \\
\hline Two years after & & $\begin{array}{c}0.799 * * \\
(0.303)\end{array}$ & $\begin{array}{c}-0.193 * * \\
(0.073)\end{array}$ & $\begin{array}{c}0.066 \\
(0.040)\end{array}$ & $\begin{array}{c}0.195 \\
(0.149)\end{array}$ & $\begin{array}{c}0.008 \\
(0.007)\end{array}$ \\
\hline $\begin{array}{l}\text { Non-frontier foreign } \\
\text { acquired }\end{array}$ & $\begin{array}{c}0.368 * * \\
(0.171)\end{array}$ & & & & & \\
\hline Year of acquisition & & $\begin{array}{l}-0.197 \\
(0.154)\end{array}$ & $\begin{array}{l}-0.020 \\
(0.041)\end{array}$ & $\begin{array}{c}0.007 \\
(0.020)\end{array}$ & $\begin{array}{l}-0.053 \\
(0.069)\end{array}$ & $\begin{array}{l}-0.000 \\
(0.000)\end{array}$ \\
\hline One year after & & $\begin{array}{l}-0.112 \\
(0.086)\end{array}$ & $\begin{array}{l}-0.023 \\
(0.044)\end{array}$ & $\begin{array}{l}-0.010 \\
(0.020)\end{array}$ & $\begin{array}{l}0.093 * \\
(0.047)\end{array}$ & $\begin{array}{l}-0.000 \\
(0.000)\end{array}$ \\
\hline Two years after & & $\begin{array}{l}-0.054 \\
(0.222)\end{array}$ & $\begin{array}{l}-0.058^{*} \\
(0.028)\end{array}$ & $\begin{array}{l}-0.010 \\
(0.046)\end{array}$ & $\begin{array}{l}-0.051 \\
(0.054)\end{array}$ & $\begin{array}{c}0.001 \\
(0.001)\end{array}$ \\
\hline Observations & 2,225 & 946 & 974 & 974 & 974 & 686 \\
\hline
\end{tabular}

Note: Fixed effects-OLS estimates. Estimated standard errors are clustered at the industry level and shown in parenthesis. Frontier foreign acquired is defined as domestic firms acquired by Japan, Germany and USA. All regressions include firmfixed effects, sector trends and year dummies. * Significant at 10\%;** Significant at 5\%; *** significant at $1 \%$.

Table 11: The Effect of Foreign Acquisition on Innovation Expenditures for a matched sample. Placebo test

\begin{tabular}{|c|c|c|c|c|c|c|}
\hline \multirow[b]{2}{*}{$\begin{array}{l}\text { Innovation } \\
\text { Expenditure } \\
\text { measure }\end{array}$} & \multicolumn{6}{|c|}{ Dependent variable: Innovation Measure } \\
\hline & $\begin{array}{c}\text { Hazard of } \\
\text { stopping } \\
\text { R\&D }\end{array}$ & Total R\&D & $\begin{array}{c}\text { Internal } \\
\text { R\&D } \\
\text { Share }\end{array}$ & $\begin{array}{l}\text { Technology } \\
\text { Transfer } \\
\text { Share }\end{array}$ & $\begin{array}{c}\text { Employees } \\
\text { with PhD }\end{array}$ & $\begin{array}{c}\text { Innovation } \\
\text { Output }\end{array}$ \\
\hline Regression No. & (i) & (ii) & (iii) & (iv) & (v) & (vi) \\
\hline $\begin{array}{l}\text { Frontier foreign } \\
\text { acquired }\end{array}$ & $\begin{array}{l}-0.306 \\
(0.580)\end{array}$ & & & & & \\
\hline Year of acquisition & & $\begin{array}{c}0.336 \\
(0.239)\end{array}$ & $\begin{array}{c}0.117 \\
(0.114)\end{array}$ & $\begin{array}{c}-0.017 \\
(0.011)\end{array}$ & $\begin{array}{c}0.044 \\
(0.051)\end{array}$ & $\begin{array}{c}-0.001 \\
(0.001)\end{array}$ \\
\hline One year after & -0.438 & $\begin{array}{l}-0.072 \\
(0.301)\end{array}$ & $\begin{array}{c}0.070 \\
(0.095)\end{array}$ & $\begin{array}{l}-0.004 \\
(0.003)\end{array}$ & $\begin{array}{c}0.241 \\
(0.174)\end{array}$ & $\begin{array}{l}-0.001 \\
(0.001)\end{array}$ \\
\hline $\begin{array}{l}\text { Non-frontier foreign } \\
\text { acquired }\end{array}$ & $(0.520)$ & & & & & \\
\hline Year of acquisition & & $\begin{array}{c}0.150 \\
(0.172)\end{array}$ & $\begin{array}{c}0.104 \\
(0.072)\end{array}$ & $\begin{array}{l}-0.018^{*} \\
(0.008)\end{array}$ & $\begin{array}{c}0.049 \\
(0.104)\end{array}$ & $\begin{array}{c}-0.000 \\
(0.000)\end{array}$ \\
\hline One year after & & $\begin{array}{c}-0.024 \\
(0.183)\end{array}$ & $\begin{array}{c}0.038 \\
(0.039) \\
\end{array}$ & $\begin{array}{l}-0.025 \\
(0.014)\end{array}$ & $\begin{array}{c}0.092 \\
(0.070)\end{array}$ & $\begin{array}{c}0.000 \\
(0.000)\end{array}$ \\
\hline Observations & 1,978 & 729 & 777 & 777 & 539 & 1,006 \\
\hline
\end{tabular}

Note: Fixed effects-OLS estimates. Estimated standard errors are clustered at the industry level and shown in parenthesis. Frontier foreign acquired is defined as domestic firms acquired by Japan, Germany and USA. All regressions include firmfixed effects, sector trends and year dummies. Total R\&D spending is the logged value. * Significant at $10 \%$;** Significant at $5 \%$; *** significant at $1 \%$. 
Figure 1: Treatment effects with externalities. Effect of foreign acquisition on total innovation expenditures of foreign and domestic firms with $90 \%$ confidence intervals

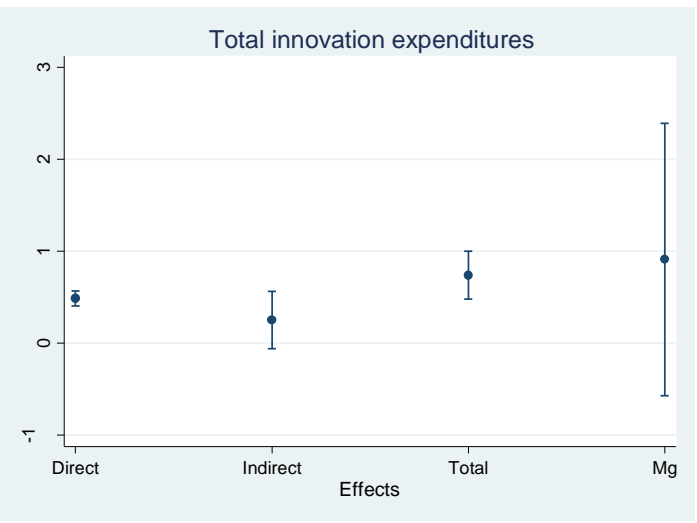

Figure 2: Treatment effects with externalities. Disaggregation by type of R\&D expenditure with $90 \%$ confidence intervals
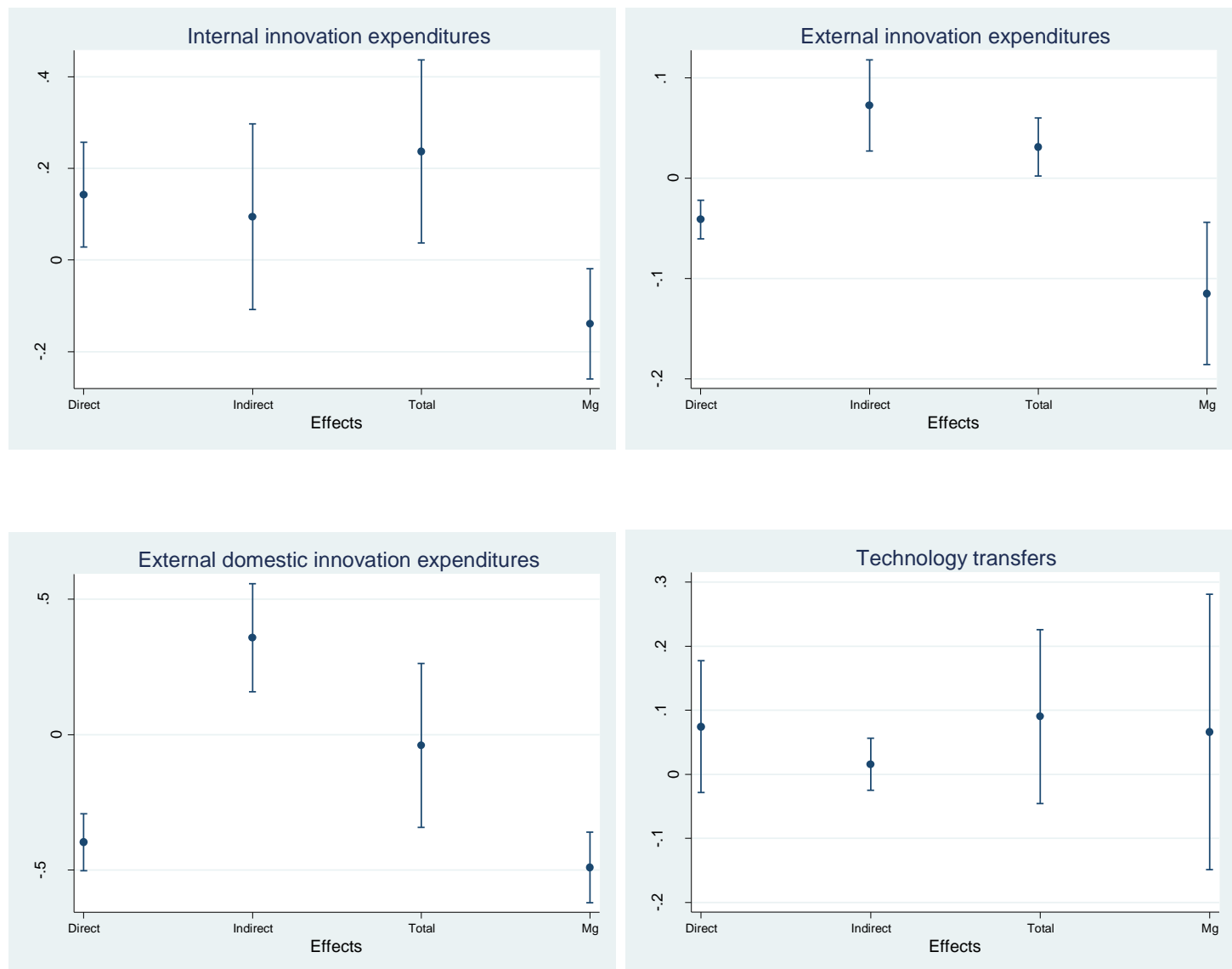
Figure 3: Treatment effects with externalities. Effect of foreign acquisition on total employees in internal R\&D of foreign and domestic firms with $90 \%$ confidence intervals
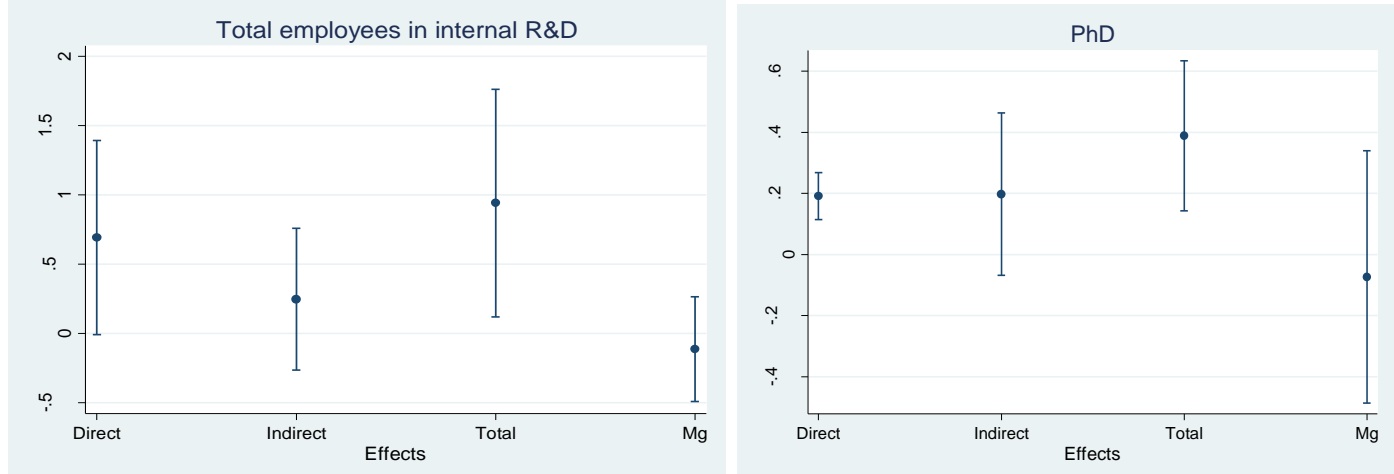


\section{ON-LINE APPENDICES}

\section{Multinationals and the Globalization of R\&D}

\section{María García-Vega, Patricia Hofmann and Richard Kneller}

\section{Table of Contents}

Appendix A

Table A1: Classification of total innovation expenditures

Table A2: The Effect of Foreign Acquisition on the Probability of Starting R\&D using a matched sample

Appendix B

Table B1: The Effect of Foreign Acquisition on the Probability of Quitting R\&D with matching procedure based on a propensity score reweighted estimation

Table B2: The Effect of Foreign Acquisition on Innovation Expenditures for a matched sample with matching procedure based on a propensity score reweighted estimation

Table B3: The Effect of Foreign Acquisition on Employment by Skill Type and Innovation Output for a matched sample with matching procedure based on a propensity score reweighted estimation

Table B4: The Effect of Foreign Acquisition on the Probability of Quitting R\&D with matching procedure based on a nearest neighbour

Table B5: The Effect of Foreign Acquisition on Innovation Expenditures for a matched sample with matching procedure based on a nearest neighbour

Table B6: The Effect of Foreign Acquisition on Employment by Skill Type and Innovation Output for a matched sample with matching procedure based on a nearest neighbour 


\section{Appendix A: Data classification and the effect of foreign acquisition on the probability of starting R\&D}

Table A1: Classification of total innovation expenditures

\begin{tabular}{l} 
Subcategories of \\
Total innovation expenditures \\
\hline$R \& D$ internal \\
$R \& D$ external \\
$R \& D$ external-domestic \\
$R \& D$ external-foreign \\
$R \& D$ external-foreign same business group \\
(Technology transfers) \\
$R \& D$ external-foreign other private
\end{tabular}

$R \& D$ external-foreign non-private

Innovation expenditures other than $R \& D$
[1-3] Definition

[1] In-house or intramural R\&D: Creative work undertaken within an enterprise on an occasional or regular basis in order to increase the stock of knowledge and its use to devise new and improved goods, services and processes.

[2] Acquisition of R\&D or extramural R\&D: Firm purchases of creative work on an occasional or regular basis in order to increase the stock of knowledge and its use to devise new and improved goods, services and processes form other companies (including other enterprises within the group) or public and private research organizations

[2.1] Acquisition of R\&D in Spain.

[2.2] Acquisition of R\&D abroad.

[2.2.1] R\&D acquisitions abroad from companies that belong to the same business group

[2.2.2] R\&D acquisitions abroad from companies that are legally independent and do not belong to the same business group

[2.2.3] R\&D acquisitions abroad from public administrations, universities, non-profit organizations and other international organizations

[3] Acquisition of machinery, equipment and software: Acquisition of advanced machinery, equipment and computer hardware or software to produce new or significantly improved goods, services, production processes, or delivery methods.

Acquisition of external knowledge: Purchase or licensing of patents and non-patented inventions, know-how, and other types of knowledge from other enterprises or organizations.

Expenditures on design functions for the development or implementation of new or improved goods, services and processes. Expenditure on design in the R\&D phase of product development should be excluded.

Internal or external training for personnel specifically for the development and/or introduction of innovations.

Expenditures on all activities concerning market preparation and introduction of new or significantly improved goods and services, including market research and launch advertising.

Note: The numbers correspond to the classification of innovation expenditures, which we use in the empirical analysis. Source: PITEC database. 
Table A2: The Effect of Foreign Acquisition on the Probability of Starting R\&D using a matched sample

\begin{tabular}{|c|c|c|}
\hline Regression No. & (i) & (ii) \\
\hline \multicolumn{3}{|c|}{ Panel A: Probability of starting R\&D during the sample period } \\
\hline Foreign acquired & $\begin{array}{c}0.061 \\
(0.043)\end{array}$ & \\
\hline Frontier foreign acquired & & $\begin{array}{c}0.048 \\
(0.050)\end{array}$ \\
\hline Non-frontier foreign acquired & & $\begin{array}{c}0.055 \\
(0.045)\end{array}$ \\
\hline Observations & 2,335 & 2,335 \\
\hline \multicolumn{3}{|c|}{ Panel B: Probability of starting R\&D in a given year } \\
\hline Foreign acquired & $\begin{array}{l}-0.022 \\
(0.014)\end{array}$ & \\
\hline Frontier foreign acquired & & $\begin{array}{c}0.000 \\
(0.001)\end{array}$ \\
\hline Non-frontier foreign acquired & & $\begin{array}{c}0.000 \\
(0.000)\end{array}$ \\
\hline Observations & 2,068 & 2,068 \\
\hline
\end{tabular}

Note: Frontier foreign acquired is defined as domestic firms acquired by Japan, Germany and USA. Panel A reports probit estimates on the probability of starting R\&D during the sample period. The dependent variable refers to whether a firm with zero internal $R \& D$ expenditures records and continues to record positive internal $R \& D$ expenditures during the sample period. We report marginal effects. Estimated standard errors are clustered at the industry level and shown in parenthesis. All regressions include industry and year dummies. * Significant at 10\%;** Significant at 5\%; *** significant at $1 \%$. 


\section{Appendix B: Results with alternative matching procedures}

In this section, we replicate our results using a propensity score reweighted estimation.

Table B1: The Effect of Foreign Acquisition on the Probability of Quitting R\&D with matching procedure based on a propensity score reweighted estimation

\begin{tabular}{lcc}
\hline \hline Regression No. & (i) & (ii) \\
\hline \multicolumn{2}{l}{ Probability of quitting R\&D in a giving year (linear probability model) } \\
\hline Foreign acquired & $0.060^{* *}$ & \\
& $(0.028)$ & \\
Frontier foreign acquired & $0.122^{* *}$ \\
& & $(0.048)$ \\
Non-frontier foreign acquired & 0.035 \\
& & $(0.029)$ \\
Observations & 35,768 & 35,125 \\
\hline \hline
\end{tabular}

Note: Frontier foreign acquired is defined as domestic firms acquired by Japan, Germany and USA. The dependent variable refers to whether a firm with positive internal $R \& D$ then become zero and remains so during the sample period. Panel A reports probit estimates on the probability of quitting R\&D during the sample period. We report marginal effects. Estimated standard errors are clustered at the industry level and shown in parenthesis. All regressions include sector trends and year dummies. Panel B reports Cox Proportional Hazard estimates. * Significant at 10\%;** Significant at 5\%; *** significant at $1 \%$.

Table B2: The Effect of Foreign Acquisition on Innovation Expenditures for a matched sample with matching procedure based on a propensity score reweighted estimation

\begin{tabular}{|c|c|c|c|c|c|c|}
\hline $\begin{array}{l}\text { Innovation Expenditure } \\
\text { Regression No. }\end{array}$ & $\begin{array}{l}\text { Total } \\
\text { (i) }\end{array}$ & $\begin{array}{c}\text { Internal } \\
\text { R\&D } \\
\text { Share } \\
\text { (ii) } \\
\end{array}$ & $\begin{array}{c}\text { External } \\
\text { R\&D } \\
\text { Share } \\
\text { (iii) } \\
\end{array}$ & $\begin{array}{c}\text { External } \\
\text { Domestic } \\
\text { Share } \\
\text { (iv) }\end{array}$ & $\begin{array}{c}\text { External } \\
\text { Foreign } \\
\text { Share } \\
(v) \\
\end{array}$ & $\begin{array}{c}\text { Technology } \\
\text { Transfers } \\
\text { Share } \\
\text { (vi) }\end{array}$ \\
\hline \multicolumn{7}{|l|}{$\begin{array}{l}\text { Frontier foreign } \\
\text { acquired }\end{array}$} \\
\hline Year of acquisition & $\begin{array}{c}0.151 \\
(0.117)\end{array}$ & $\begin{array}{l}-0.065 \\
(0.037)\end{array}$ & $\begin{array}{c}0.018 \\
(0.028)\end{array}$ & $\begin{array}{c}0.046 \\
(0.084)\end{array}$ & $\begin{array}{l}-0.030 \\
(0.020)\end{array}$ & $\begin{array}{c}0.088 * * \\
(0.034)\end{array}$ \\
\hline One year after & $\begin{array}{c}0.297 * * \\
(0.110)\end{array}$ & $\begin{array}{c}-0.067 * * \\
(0.026)\end{array}$ & $\begin{array}{c}0.023 \\
(0.031)\end{array}$ & $\begin{array}{c}0.034 \\
(0.074)\end{array}$ & $\begin{array}{l}-0.028 \\
(0.016)\end{array}$ & $\begin{array}{c}0.044 \\
(0.057)\end{array}$ \\
\hline Two years after & $\begin{array}{c}0.795 * * \\
(0.300)\end{array}$ & $\begin{array}{c}-0.122 * * * \\
(0.037)\end{array}$ & $\begin{array}{l}0.063 * * \\
(0.021)\end{array}$ & $\begin{array}{c}0.452 * * * \\
(0.109)\end{array}$ & $\begin{array}{l}-0.027 \\
(0.016)\end{array}$ & $\begin{array}{c}0.085 \\
(0.060)\end{array}$ \\
\hline \multicolumn{7}{|l|}{$\begin{array}{l}\text { Non-frontier foreign } \\
\text { acquired }\end{array}$} \\
\hline Year of acquisition & $\begin{array}{l}-0.068 \\
(0.102)\end{array}$ & $\begin{array}{l}-0.007 \\
(0.023)\end{array}$ & $\begin{array}{c}0.029 \\
(0.020)\end{array}$ & $\begin{array}{l}-0.022 \\
(0.059)\end{array}$ & $\begin{array}{l}-0.003 \\
(0.007)\end{array}$ & $\begin{array}{c}0.020 \\
(0.017)\end{array}$ \\
\hline One year after & $\begin{array}{l}-0.092 \\
(0.056)\end{array}$ & $\begin{array}{l}-0.009 \\
(0.033)\end{array}$ & $\begin{array}{c}0.001 \\
(0.012)\end{array}$ & $\begin{array}{l}-0.032 \\
(0.054)\end{array}$ & $\begin{array}{l}-0.003 \\
(0.006)\end{array}$ & $\begin{array}{c}0.006 \\
(0.013)\end{array}$ \\
\hline Two years after & $\begin{array}{l}-0.030 \\
(0.222) \\
\end{array}$ & $\begin{array}{l}-0.062 * \\
(0.029) \\
\end{array}$ & $\begin{array}{c}0.011 \\
(0.042) \\
\end{array}$ & $\begin{array}{r}0.018 \\
(0.118) \\
\end{array}$ & $\begin{array}{l}-0.015 \\
(0.020) \\
\end{array}$ & $\begin{array}{r}0.014 \\
(0.030) \\
\end{array}$ \\
\hline Observations & 14,147 & 14,147 & 14,147 & 14,147 & 14,147 & 14,147 \\
\hline
\end{tabular}

Note: Fixed effects-OLS estimates. Estimated standard errors are clustered at the industry level and shown in parenthesis. Frontier foreign acquired is defined as domestic firms acquired by Japan, Germany and USA. All regressions include firmfixed effects, sector trends and year dummies. Total R\&D spending is the logged value. Internal and external R\&D expenditures are sub-components of total innovation expenditures and are expressed as shares of this total. Internal R\&D is the $R \& D$ undertaken within the firm; External $R \& D$ is the purchases of $R \& D$ by the firm; External domestic and external foreign are sub-components of external R\&D. External domestic is the R\&D acquired in Spain by the firm and external foreign are the imports of R\&D. Technology transfers is a sub-component of external foreign. Technology transfers are the imports of R\&D from the business group by the firm. * Significant at $10 \%$;* Significant at $5 \%$; *** significant at $1 \%$. 
Table B3: The Effect of Foreign Acquisition on Employment by Skill Type and Innovation Output for a matched sample with matching procedure based on a propensity score reweighted estimation

\begin{tabular}{|c|c|c|c|c|c|c|}
\hline $\begin{array}{l}\text { Employees in Internal } \\
\text { R\&D measure: } \\
\text { Regression No. }\end{array}$ & Total & $\begin{array}{l}\text { With } \\
\text { Ph.D. } \\
\text { (ii) }\end{array}$ & $\begin{array}{l}\text { With 5-year } \\
\text { Undergrad } \\
\text { degree } \\
\text { (iii) }\end{array}$ & $\begin{array}{c}\text { With 3- } \\
\text { year } \\
\text { Undergrad } \\
\text { degree } \\
\text { (iv) }\end{array}$ & $\begin{array}{l}\text { Without } \\
\text { higher } \\
\text { education } \\
\text { (v) }\end{array}$ & $\begin{array}{c}\text { Innovation } \\
\text { Output }\end{array}$ \\
\hline \multicolumn{7}{|l|}{$\begin{array}{l}\text { Frontier foreign } \\
\text { acquired }\end{array}$} \\
\hline Year of acquisition & $\begin{array}{c}0.146 \\
(0.148)\end{array}$ & $\begin{array}{c}0.075 * * * \\
(0.022)\end{array}$ & $\begin{array}{c}0.235 \\
(0.180)\end{array}$ & $\begin{array}{c}-0.078 \\
(0.118)\end{array}$ & $\begin{array}{c}0.079 \\
(0.078)\end{array}$ & $\begin{array}{l}-0.000 \\
(0.001)\end{array}$ \\
\hline One year after & $\begin{array}{c}0.128 \\
(0.173)\end{array}$ & $\begin{array}{c}0.027 \\
(0.019)\end{array}$ & $\begin{array}{c}0.256 \\
(0.238)\end{array}$ & $\begin{array}{c}-0.010 \\
(0.110)\end{array}$ & $\begin{array}{c}0.049 \\
(0.103)\end{array}$ & $\begin{array}{c}0.006 * * * \\
(0.002)\end{array}$ \\
\hline Two years after & $\begin{array}{l}0.351 * \\
(0.173)\end{array}$ & $\begin{array}{c}0.234 \\
(0.174)\end{array}$ & $\begin{array}{c}0.288 \\
(0.321)\end{array}$ & $\begin{array}{l}0.522 * \\
(0.246)\end{array}$ & $\begin{array}{c}0.771 \\
(0.463)\end{array}$ & $\begin{array}{c}0.012 \\
(0.007)\end{array}$ \\
\hline \multicolumn{7}{|l|}{$\begin{array}{l}\text { Non-frontier foreign } \\
\text { acquired }\end{array}$} \\
\hline Year of acquisition & $\begin{array}{c}-0.045 \\
(0.055)\end{array}$ & $\begin{array}{l}0.053^{*} \\
(0.024)\end{array}$ & $\begin{array}{c}-0.203^{* * *} * \\
(0.059)\end{array}$ & $\begin{array}{c}0.068 \\
(0.103)\end{array}$ & $\begin{array}{c}0.064 \\
(0.095)\end{array}$ & $\begin{array}{l}-0.000 \\
(0.001)\end{array}$ \\
\hline One year after & $\begin{array}{l}-0.109 \\
(0.139)\end{array}$ & $\begin{array}{c}0.109 * * \\
(0.034)\end{array}$ & $\begin{array}{l}-0.183 \\
(0.107)\end{array}$ & $\begin{array}{c}-0.079 \\
(0.094)\end{array}$ & $\begin{array}{l}-0.006 \\
(0.068)\end{array}$ & $\begin{array}{l}-0.000 \\
(0.001)\end{array}$ \\
\hline Two years after & $\begin{array}{l}-0.110 \\
(0.178) \\
\end{array}$ & $\begin{array}{c}0.030 \\
(0.038) \\
\end{array}$ & $\begin{array}{r}-0.153 \\
(0.145) \\
\end{array}$ & $\begin{array}{l}-0.137 \\
(0.176) \\
\end{array}$ & $\begin{array}{c}0.055 \\
(0.146) \\
\end{array}$ & $\begin{array}{c}0.001 \\
(0.001) \\
\end{array}$ \\
\hline Observations & 14,147 & 14,147 & 14,147 & 14,147 & 14,147 & 10,288 \\
\hline
\end{tabular}

Note: Fixed effects-OLS estimates. Estimated standard errors are clustered at the industry level and shown in parenthesis. Frontier foreign acquired is defined as domestic firms acquired by Japan, USA and Germany. All regressions include firmfixed effects, sector and year dummies. * Significant at 10\%;* Significant at 5\%; *** significant at $1 \%$.

In this section, we replicate our estimations using a nearest neighbour matching procedure

Table B4: The Effect of Foreign Acquisition on the Probability of Quitting R\&D with matching procedure based on a nearest neighbour

\begin{tabular}{|c|c|c|}
\hline Regression No. & (i) & (ii) \\
\hline \multicolumn{3}{|c|}{ Panel A: Probability of quitting R\&D during sample period } \\
\hline Foreign acquired & $\begin{array}{c}0.104 * \\
(0.054)\end{array}$ & \\
\hline Frontier foreign acquired & & $\begin{array}{c}0.149 * * * \\
(0.045)\end{array}$ \\
\hline Non-frontier foreign acquired & & $\begin{array}{l}0.115^{*} \\
(0.067)\end{array}$ \\
\hline Observations & 2,445 & 2,445 \\
\hline \multicolumn{3}{|c|}{ Panel B: Probability of quitting $R \& D$ in a giving year (hazard rate) } \\
\hline Foreign acquired & $\begin{array}{c}0.335 * * * \\
(0.121)\end{array}$ & \\
\hline Frontier foreign acquired & & $\begin{array}{c}0.573 * * * \\
(0.177)\end{array}$ \\
\hline Non-frontier foreign acquired & & $\begin{array}{c}0.188 \\
(0.190)\end{array}$ \\
\hline Observations & 2,370 & 2,370 \\
\hline
\end{tabular}

Note: Frontier foreign acquired is defined as domestic firms acquired by Japan, Germany and USA. The dependent variable refers to whether a firm with some internal R\&D stops and after stopping never continues having internal R\&D during the sample period. We report marginal effects. Estimated standard errors are clustered at the industry level and shown in parenthesis. All regressions include sector dummies as controls. * Significant at 10\%;** Significant at 5\%; *** significant at $1 \%$. 
Table B5: The Effect of Foreign Acquisition on Innovation Expenditures for a matched sample with matching procedure based on a nearest neighbour

\begin{tabular}{|c|c|c|c|c|c|c|}
\hline $\begin{array}{l}\text { Innovation Expenditure } \\
\text { Regression No. }\end{array}$ & $\begin{array}{c}\text { Total } \\
\text { (i) }\end{array}$ & $\begin{array}{c}\text { Internal } \\
\text { R\&D } \\
\text { Share } \\
\text { (ii) }\end{array}$ & $\begin{array}{c}\text { External } \\
\text { R\&D } \\
\text { Share } \\
\text { (iii) }\end{array}$ & $\begin{array}{c}\text { External } \\
\text { Domestic } \\
\text { Share } \\
\text { (iv) }\end{array}$ & $\begin{array}{c}\text { External } \\
\text { Foreign } \\
\text { Share } \\
\text { (v) }\end{array}$ & $\begin{array}{c}\text { Technology } \\
\text { Transfers } \\
\text { Share } \\
\text { (vi) }\end{array}$ \\
\hline \multicolumn{7}{|c|}{ Frontier foreign acquired } \\
\hline Year of acquisition & $\begin{array}{c}0.136 \\
(0.088)\end{array}$ & $\begin{array}{l}-0.064 * \\
(0.032)\end{array}$ & $\begin{array}{c}0.011 \\
(0.020)\end{array}$ & $\begin{array}{c}0.042 \\
(0.068)\end{array}$ & $\begin{array}{l}-0.039 \\
(0.029)\end{array}$ & $\begin{array}{l}0.084 * * * \\
(0.025)\end{array}$ \\
\hline One year after & $\begin{array}{c}0.165 \\
(0.127)\end{array}$ & $\begin{array}{l}-0.076^{*} \\
(0.037)\end{array}$ & $\begin{array}{c}0.001 \\
(0.021)\end{array}$ & $\begin{array}{l}-0.021 \\
(0.062)\end{array}$ & $\begin{array}{c}-0.075 * * \\
(0.032)\end{array}$ & $\begin{array}{c}0.035 \\
(0.055)\end{array}$ \\
\hline Two years after & $\begin{array}{l}0.970 * * \\
(0.325)\end{array}$ & $\begin{array}{l}-0.128 \\
(0.088)\end{array}$ & $\begin{array}{c}0.008 \\
(0.016)\end{array}$ & $\begin{array}{l}0.287 * * \\
(0.095)\end{array}$ & $\begin{array}{c}-0.068 * * \\
(0.023)\end{array}$ & $\begin{array}{c}0.047 \\
(0.066)\end{array}$ \\
\hline \multicolumn{7}{|l|}{$\begin{array}{l}\text { Non-frontier foreign } \\
\text { acquired }\end{array}$} \\
\hline Year of acquisition & $\begin{array}{c}- \\
0.394 * * * \\
(0.110)\end{array}$ & $\begin{array}{l}-0.010 \\
(0.049)\end{array}$ & $\begin{array}{c}0.008 \\
(0.019)\end{array}$ & $\begin{array}{c}0.000 \\
(0.043)\end{array}$ & $\begin{array}{l}-0.024 \\
(0.013)\end{array}$ & $\begin{array}{c}0.014 \\
(0.022)\end{array}$ \\
\hline One year after & $\begin{array}{c}- \\
0.413 * * * \\
(0.115)\end{array}$ & $\begin{array}{c}0.004 \\
(0.032)\end{array}$ & $\begin{array}{l}-0.016 \\
(0.020)\end{array}$ & $\begin{array}{c}0.017 \\
(0.069)\end{array}$ & $\begin{array}{l}-0.025 \\
(0.019)\end{array}$ & $\begin{array}{l}-0.031 \\
(0.027)\end{array}$ \\
\hline Two years after & $\begin{array}{l}-0.373 \\
(0.206) \\
\end{array}$ & $\begin{array}{l}-0.015 \\
(0.046) \\
\end{array}$ & $\begin{array}{l}-0.010 \\
(0.042) \\
\end{array}$ & $\begin{array}{l}-0.027 \\
(0.139) \\
\end{array}$ & $\begin{array}{l}-0.066 \\
(0.042) \\
\end{array}$ & $\begin{array}{l}-0.011 \\
(0.047) \\
\end{array}$ \\
\hline Observations & 1,026 & 1,057 & 1,057 & 1,057 & 1,057 & 1,057 \\
\hline
\end{tabular}

Table B6: The Effect of Foreign Acquisition on Employment by Skill Type and Innovation Output for a matched sample with matching procedure based on a nearest neighbour

\begin{tabular}{|c|c|c|c|c|c|c|}
\hline $\begin{array}{l}\text { Employees in Internal } \\
\text { R\&D measure: } \\
\text { Regression No. }\end{array}$ & Total & $\begin{array}{l}\text { With } \\
\text { Ph.D. } \\
\text { (ii) }\end{array}$ & $\begin{array}{l}\text { With 5- } \\
\text { year } \\
\text { Undergrad } \\
\text { degree } \\
\text { (iii) }\end{array}$ & $\begin{array}{l}\text { With 3- } \\
\text { year } \\
\text { Undergrad } \\
\text { degree } \\
\text { (iv) }\end{array}$ & $\begin{array}{l}\text { Without } \\
\text { higher } \\
\text { education } \\
\text { (v) }\end{array}$ & $\begin{array}{c}\text { Innovation } \\
\text { Output } \\
\text { (vi) }\end{array}$ \\
\hline \multicolumn{7}{|l|}{$\begin{array}{l}\text { Frontier foreign } \\
\text { acquired }\end{array}$} \\
\hline Year of acquisition & $\begin{array}{c}0.146 \\
(0.226)\end{array}$ & $\begin{array}{c}0.081 * * * \\
(0.022)\end{array}$ & $\begin{array}{c}0.256 \\
(0.192)\end{array}$ & $\begin{array}{l}-0.023 \\
(0.112)\end{array}$ & $\begin{array}{c}0.098 \\
(0.139)\end{array}$ & $\begin{array}{c}0.001 \\
(0.001)\end{array}$ \\
\hline One year after & $\begin{array}{c}0.122 \\
(0.170)\end{array}$ & $\begin{array}{c}0.008 \\
(0.044)\end{array}$ & $\begin{array}{c}0.217 \\
(0.217)\end{array}$ & $\begin{array}{c}0.005 \\
(0.147)\end{array}$ & $\begin{array}{c}0.087 \\
(0.146)\end{array}$ & $\begin{array}{l}0.002 * * \\
(0.001)\end{array}$ \\
\hline Two years after & $\begin{array}{l}0.425^{*} \\
(0.209)\end{array}$ & $\begin{array}{c}0.228 \\
(0.182)\end{array}$ & $\begin{array}{c}0.210 \\
(0.291)\end{array}$ & $\begin{array}{c}0.589 * * \\
(0.239)\end{array}$ & $\begin{array}{c}0.654 \\
(0.427)\end{array}$ & $\begin{array}{c}0.008 \\
(0.007)\end{array}$ \\
\hline \multicolumn{7}{|l|}{$\begin{array}{l}\text { Non-frontier foreign } \\
\text { acquired }\end{array}$} \\
\hline Year of acquisition & $\begin{array}{c}-0.221 * * * \\
(0.061)\end{array}$ & $\begin{array}{l}-0.094 \\
(0.102)\end{array}$ & $\begin{array}{c}-0.221 * * * \\
(0.050)\end{array}$ & $\begin{array}{l}-0.019 \\
(0.044)\end{array}$ & $\begin{array}{l}-0.089 \\
(0.095)\end{array}$ & $\begin{array}{c}0.001 \\
(0.001)\end{array}$ \\
\hline One year after & $\begin{array}{c}-0.302 * * * \\
(0.092)\end{array}$ & $\begin{array}{c}0.063 \\
(0.059)\end{array}$ & $\begin{array}{c}-0.247 * * \\
(0.087)\end{array}$ & $\begin{array}{l}-0.145 \\
(0.105)\end{array}$ & $\begin{array}{l}-0.148 \\
(0.100)\end{array}$ & $\begin{array}{c}0.000 \\
(0.001)\end{array}$ \\
\hline Two years after & $\begin{array}{c}-0.264 * * \\
(0.101)\end{array}$ & $\begin{array}{l}-0.079 \\
(0.086)\end{array}$ & $\begin{array}{l}-0.133 \\
(0.142)\end{array}$ & $\begin{array}{l}-0.090 \\
(0.201)\end{array}$ & $\begin{array}{l}-0.080 \\
(0.167)\end{array}$ & $\begin{array}{c}0.001 \\
(0.001)\end{array}$ \\
\hline Observations & 1,057 & 1,057 & 1,057 & 1,057 & 1,057 & 744 \\
\hline
\end{tabular}

Note: Fixed effects-OLS estimates. Estimated standard errors are clustered at the industry level and shown in parenthesis. Frontier foreign acquired is defined as domestic firms acquired by Japan, USA and Germany. All regressions include firmfixed effects, sector trends and year dummies. In columns (vi), the innovation output is the number of patents over a 3-year time period. * Significant at $10 \% ; * *$ Significant at $5 \%$; *** significant at $1 \%$. 